\title{
EXCHANGE RATES, REMITTANCES, AND COMPETITIVENESS IN HAITI
}

Eugenio Díaz-Bonilla, Flor Paz, and Valeria Piñeiro 


\section{CONTENTS}

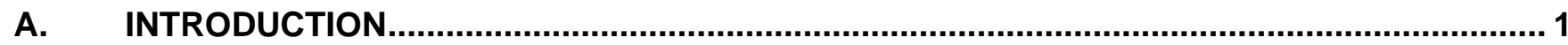

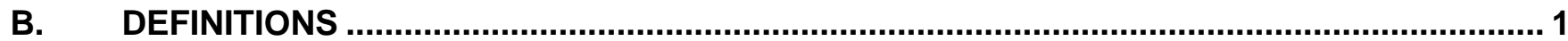

C. EVOLUTION OF EXCHANGE RATES, NOMINAL AND REAL ............................................ 3

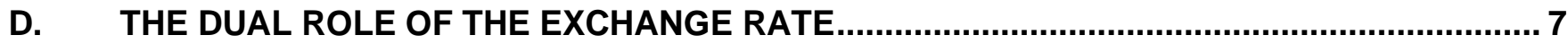

E. EQUILIBIRUM RERS, MISALIGNMENTS, OVERVALUATION AND UNDERVALUATION ...... 9

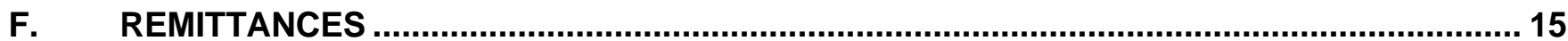

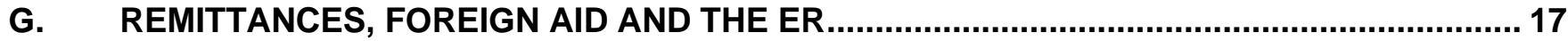

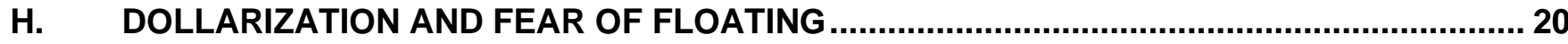

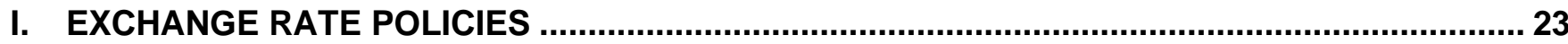

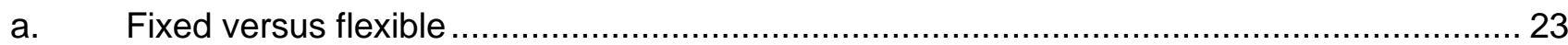

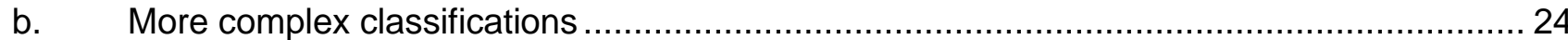

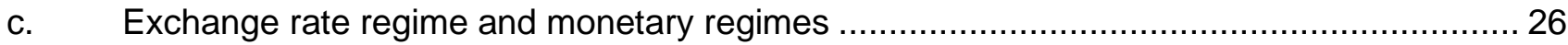

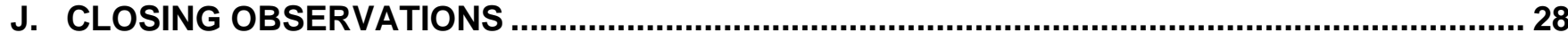

ANNEX

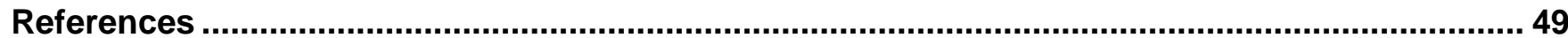

\section{TABLES}

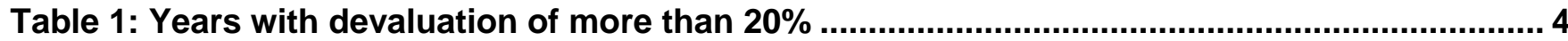

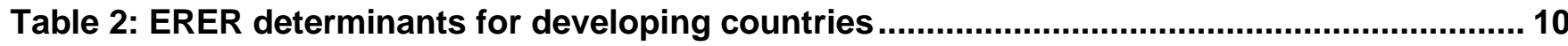

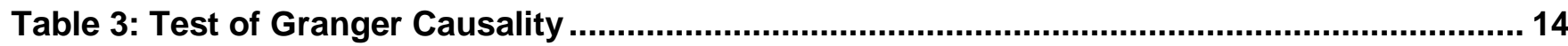

Table 4: Economic performance under fixed and flexible regimes ................................................. 24

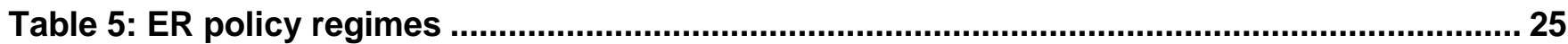

Table 6: Exchange rate and monetary policy regimes ................................................................... 27

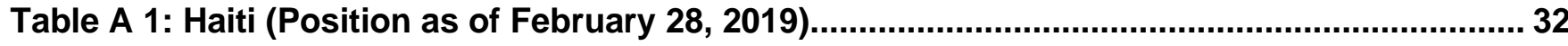

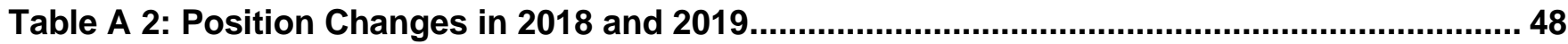

\section{CHARTS}

Chart 1: Exchange Rate (Gourdes per US dollar) ......................................................................... 3 


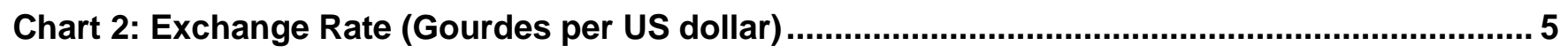

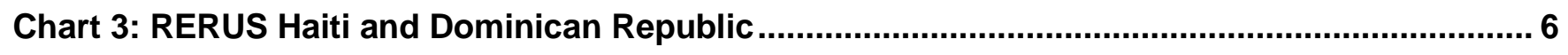

Chart 4: RER Haiti / Dominican Republic .................................................................................... 7

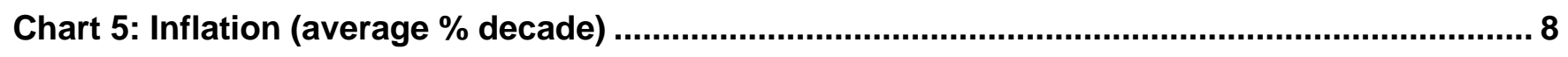

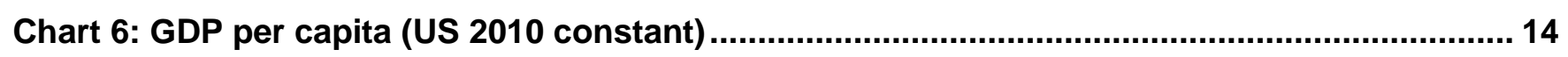

Chart 7: Migrant remittance inflows (US\$ million) .................................................................. 15

Chart 8: Remittances in millions of current dollars............................................................. 18

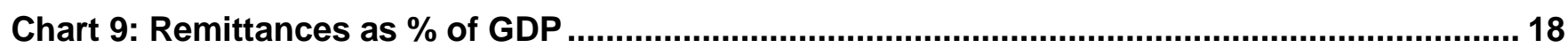

Chart 10: Remittances and Grants per capita .................................................................. 19

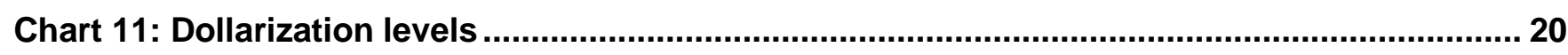

Chart 12: Foreign Deposits \% M3 ........................................................................................... 21

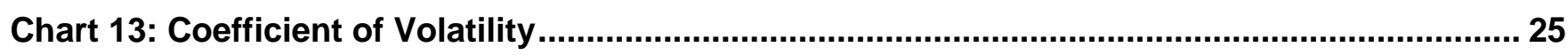




\section{A. INTRODUCTION}

The exchange rate $(E R)$ is one of the most important macroeconomic variables in the economy, defining the price of the domestic currency in relation to a foreign currency or currencies. The level and changes (both actual and expected) of the ER (nominal and real, defined below) have wide influence throughout the economy, affecting and being affected by the demand and supply of traded and nontraded goods and services, the demand and supply of money and monetary assets denominated in local currency in comparison with assets denominated in other currencies, and inflows or outflows of capitals and remittances, among main key variables. In consequence, the ER and ER policies influence growth, employment, inflation, international trade, and banking and fiscal stability (a classical general treatment can be found in Krueger 1983; see also Corden 1990).

In what follows we present some definitions (Section B). Section C shows the historical evolution of ERs. Section D discusses the dual role of ERs both for competitiveness and as nominal anchor, characteristic that is at the center of many macroeconomic inconsistencies. Section $E$ discusses the concepts of equilibrium ER and misalignments. Section $F$ analyzes remittances and Section $G$ the impact on ER. Dollarization and its consequences are covered in Section $\mathrm{H}$. Section I looks at different aspects of ER policies and their combination with monetary regimes. Section $\mathrm{J}$ closes with several suggestions about ER policies in the context of consistent macroeconomic programs.

\section{B. DEFINITIONS}

To analyze exchange rate policies, it is necessary to first consider some definitions. Nominal exchange rates (NER) are usually defined in units of domestic currency per unit of foreign currency (for instance, 80 gourdes per US dollar). ${ }^{1}$ With that definition, appreciation (depreciation) of a currency means that the amount of that currency paid for one unit of foreign currency decreases (increases). A strong (weak) currency is one that has appreciated (depreciated) vis-à-vis others. ${ }^{2}$

\footnotetext{
1 There are some exceptions, such as the British sterling pound, which is usually quoted as dollars per pound. Also, it should be noted the concept of effective nominal exchange rate (ENER) that highlights the fact that a country has different exchange rates with different currencies, such as $x$ gourdes per dollar, $y$ gourdes per euro, $z$ gourdes per yen, and so on. The ENER is calculated as an index that represents an average of all those exchange rates weighted by the percentage of international trade of a country with each one of those currency areas.

${ }^{2}$ Note that when the domestic currency has appreciated and is "strong", the nominal value of the ER so defined goes down (for instance, if the ER moves from 80 gourdes per dollar to 60 gourdes per dollar, the domestic currency has appreciated or "strengthened"). Conversely, when a currency depreciates (or "weakens"), the nominal value of ER goes up. This is sometimes a source of confusion.
} 
Another important concept is the real exchange rate (RER), which is calculated in two main ways. The first one, in the case of a single partner country, is the bilateral nominal exchange rate of the home country with the foreign country corrected by an index of domestic prices and another index of prices in that partner country:

$$
\text { RER1 }=\left(E^{\star} \text { Pint }\right) / \text { Pdom, }
$$

where Pint is the price index of the partner country and Pdom is the local price index. ${ }^{3}$ Therefore the nominal ER is adjusted by the differential in inflation between the country analyzed and the other one used as comparison. ${ }^{4}$

Another definition of the real exchange rate is the price of traded goods and services (Ptr) in a country divided by the price of nontraded ones (Pntr) in that same country:

$$
\text { RER2 }=\text { Ptr/Pntr. }
$$

Usually, for this definition there is no information about the prices of tradable and nontradable goods and services (which is the case of Haiti), and therefore, the definition RER1 is generally utilized (which we do here). ${ }^{5}$ In any case, a devaluation of the nominal exchange rate (NER) increases, at least initially, ${ }^{6}$ the values of both RER1 and RER2; then it is said that they have depreciated (conversely, with the appreciation of the ER, both RER1 and RER2 decline).

Note that, as with the nominal definitions, the ratios move opposite to the normal meaning of the words involved: the RERs increase when they depreciate and decrease when appreciating. That is why analysts sometimes use definitions in which the ratios are inverted. These alternative definitions are a source of confusion in the literature, and it is always important to clarify what definition is being used. Here we use the equation for RER1 using the US dollar as the reference currency, but also comparing with the currency of the Dominican Republic.

\footnotetext{
${ }^{3}$ Usually, it is the consumption price index, but it is possible to use others, such as wholesale price indexes, producer price indexes, and GDP deflators. Chinn (2005) discusses the advantages and disadvantages of various price indexes that can be utilized.

${ }^{4}$ In this economic context the word "real" is used in the specific meaning of "adjusted by inflation." As it was in the case of the effective nominal exchange rate, this formula can be generalized to more than just another currency, by calculating a geometrical average of the bilateral real exchange rates, weighted as before. This is called an effective real exchange rate (ERER).

${ }^{5}$ In Díaz-Bonilla 2015, there is a discussion of the relationships between RER1 and RER2.

${ }^{6}$ The final effects depend on the successive rounds of reactions of Pdom to the devaluation.
} 


\section{EVOLUTION OF EXCHANGE RATES, NOMINAL AND REAL}

Chart 1 shows the evolution of the NER in Haiti since the 1960s.

\section{Chart 1: Exchange Rate (Gourdes per US dollar)}

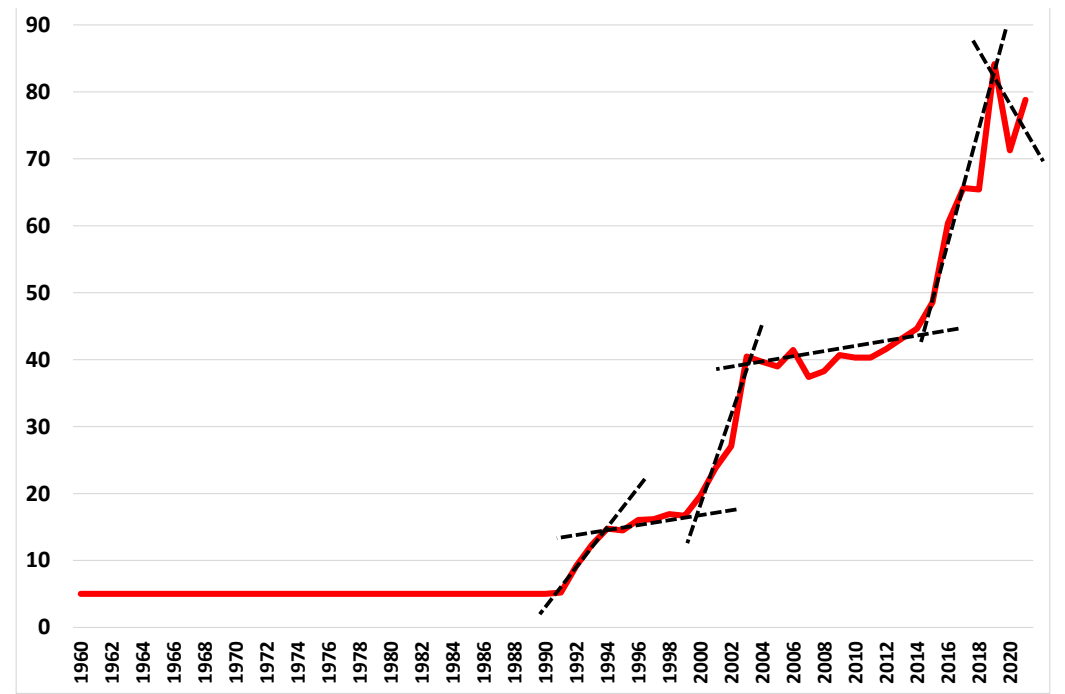

Source: WDI/WB

After a long period of keeping the gourde tied to the US dollar at fixed rates (5 gourdes), that situation became untenable given the differential inflation with the US, and the fixed parity was abandoned in the early 1990s. Since then, the gourde evolved with a pattern of sharp devaluations, apparently related to political problems (see Table 1), after which there were attempts to stabilize the gourde at the new higher rate, until another political problem led to the currency jumping again. The last devaluation in 2019 is somewhat different because it was followed by a sharp appreciation, instead of the previous pattern of trying to stabilize the gourde at the higer level after the devaluation (more on this later). Table 1 shows the years with devaluations above $20 \%$ and a narrative with the political and other problems experienced those years. 


\section{Table 1: Years with devaluation of more than $20 \%$}

Annual

devaluation (\%)

\section{Political conditions and other relevant events}

1992

76.2

1993

2001

2003

2016

24.3

2019

34.5
1991 - Coup d'etat ousting Aristideled by Brigadier-General Raoul Cedras. Sanctions by the US and the Organisation of American States from 1992-1994.

Continuation of sanctions and expectation of a US direct militar intervention against military government

2000 November - Aristide elected president. Unrest during mid to end of 2001, with the government accusing former army officers of trying another coup d'etat. In July. armed men attack three police locations, killing four police officers. In December - Armed men tried to occupy the National Palace in what appeared a coup; 12 people are killed in the raid.

Approaching celebration of 200 anniversary of Haiti is utilized by opponents to Aristide to stage protests that end up forcing his resignation early in 2004

2016 February - Michel Martelly ends his presidential term without handing power to a successor because the second round of the presidential election was postponed without a firm date. Parliament appoints Jocelerme Privert as interim president. In October, Haiti was hit by Hurricane Matthew, the strongest in a decade, killing hundreds.

Venezuela had stopped shipping oil to Haiti in March 2018, leading to fuel shortages. The government removed subsidies to fosil fuels in July leading to increases of over 50 percent. This started a series of protestes that moved from the prices of energy, to complaints about corruption, democracy, and security (given increases in killings), that ended up with what was called "Peyi lok" or "country lockdown"

Source: WDI/WB, and BBC timeline for Haiti

As noted that pattern was changed after the last devaluation. Chart 2 shows the last months, when the Central Bank engineered a sharp appreciation of the gourde, that is being partially reverted now, but not reaching yet previous nominal levels. 


\section{Chart 2: Exchange Rate (Gourdes per US dollar)}

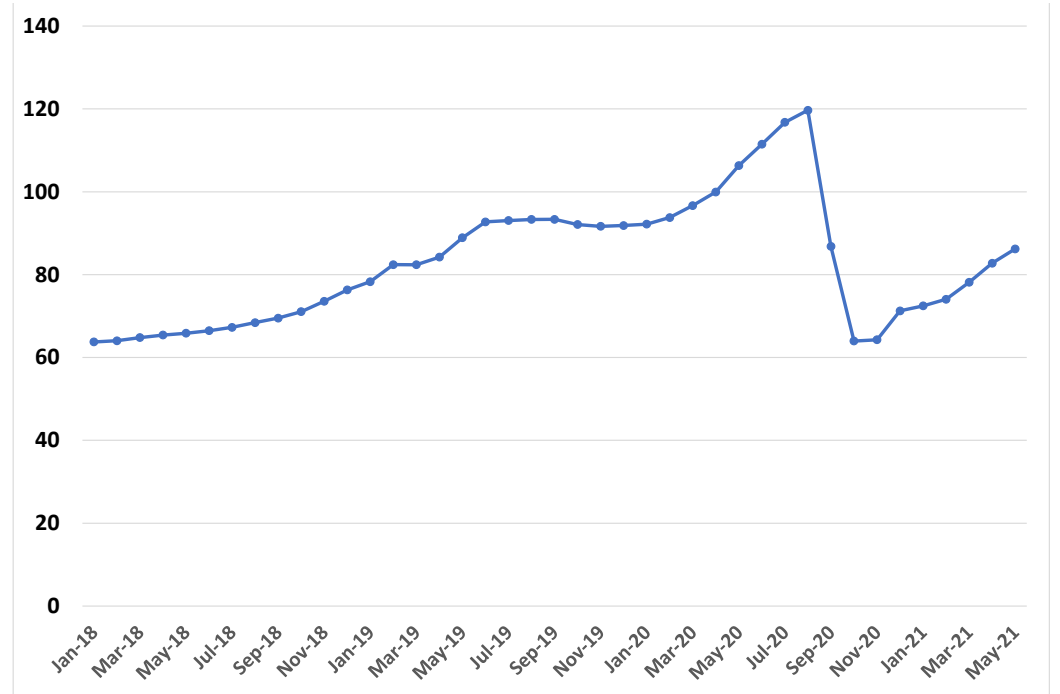

Source: Central Bank of Haiti.

One of the reasons of the appreciation seems to have been concerns about inflationary pressures in the context of COVID-19. Monthly inflation rate, that was already relatively high at $1.6-1.8 \%$ per month at the end of 2019 and early 2020, accelerated since the pandemic, peaking in August 2020 at 3.3\% per month (which made the inflation from that month to the same month in 2019 almost $28 \%$ on a yearto-year basis). Since then, inflation has turned negative for two months, due to the drastic appreciation of the ER that reduced the price of imported products, including food and fuels. But while the latter product is not produced domestically, food is, and the devaluation opened a gap against Haitian products. After that, the gourde was allowed to devalue somewhat, and inflation has turned positive again but at lower rates.

Moving now to the RER, Chart 3 compares the evolution of that variable in Haiti and the Dominican Republic. 


\section{Chart 3: RERUS Haiti and Dominican Republic}

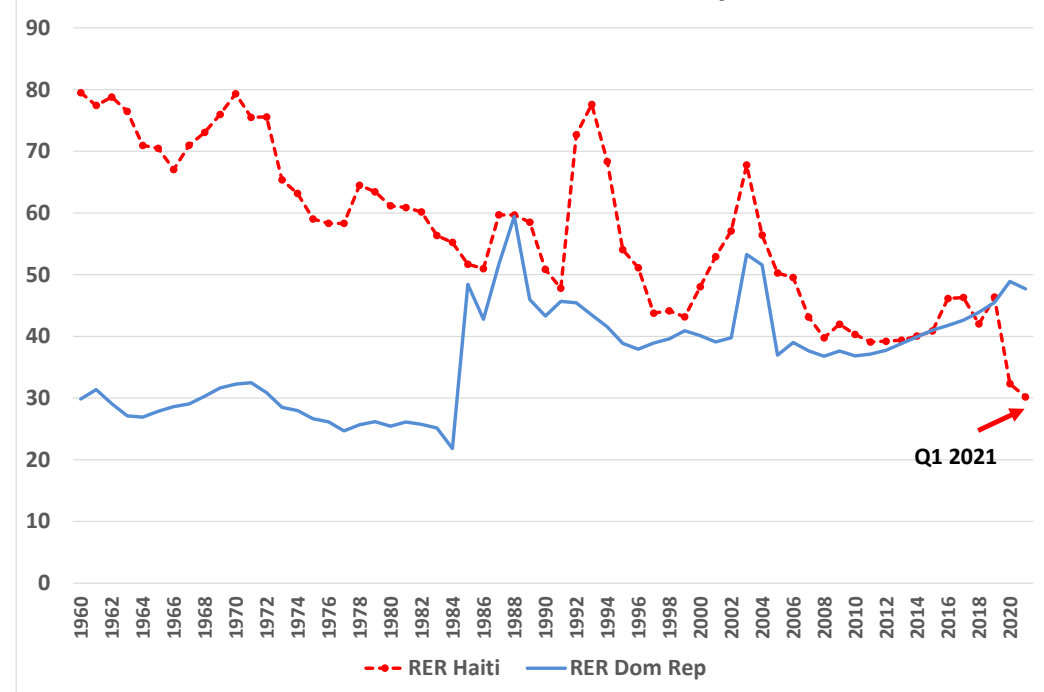

Source: Authors using data from the WDI/WB, and Central Banks from Haiti and Dominican Republic.

While as mentioned Haiti devalued the gourde in 1991 after many years of keeping it at 5:1 with the US dollar, the Dominican Republic (which had the peso tied 1:1 with the US dollar), had abandoned the parity earlier in 1985, also because the keeping a fixed exchange rate was untenable given the differential inflation with the US. Although both currencies started a process of depreciation since then, the Dominican Republic maintained the RER within some more stable range after the devaluation of the mid 1980s, while Haiti shows a pattern of continuous appreciation of the RER against the US dollar, particularly accentuated during the last months, due to the strong appreciation of the nominal exchange rate.

After the 1980s devaluation in the Dominican Republic, which made the Dominican peso more competitive compared to the gourde, this differential behavior of the RER in both countries has led to a small but persistent appreciation of the Haitian currency also against the peso, which was aggravated in the last year (See Chart 4). 


\section{Chart 4: RER Haiti / Dominican Republic}

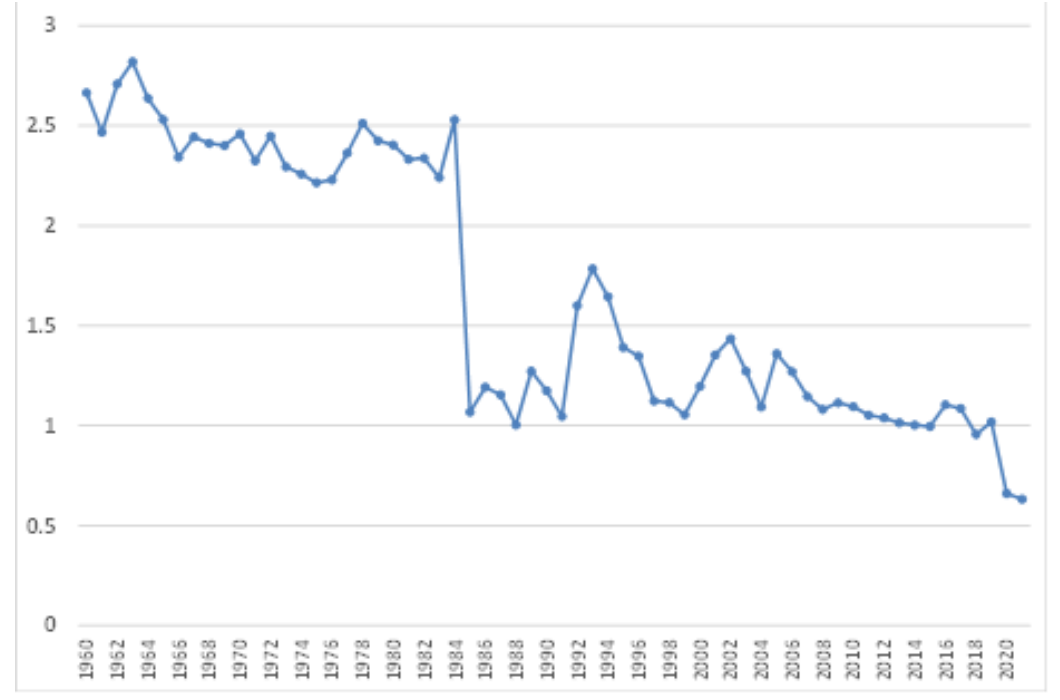

Source: authors based on data from WDI/Wb

The appreciation of the gourde both against the US dollar and against the Dominican peso must exert a negative effect on the Haitian economy regarding growth, employment, and trade.

The patter of a devaluation followed by the attempt to stabilize the nominal ER at a higher level is related to a basic duality at the heart of ER policies, as discussed immediately.

\section{THE DUAL ROLE OF THE EXCHANGE RATE}

As mentioned before, the ER is one of the key macro prices (if not the key macro-price) in the economy, particularly in developing countries. A crucial problem to define the adequate level of the ER is that it plays a dual role in the nominal and real aspects of the economy. That dual role of the exchange rate is reflected in the two approaches to exchange rate policy that have been utilized in developing countries. The real exchange rate approach emphasizes the influence of the exchange rate on production, employment, and trade (see Balassa 1977a, 1977b, and 1985). The focus of this approach is the evolution of some variant of the RER equation discussed before, to evaluate the international competitiveness of the economy. On the other hand, the nominal anchor approach highlights the role of the exchange rate in the inflationary process and its relationship with interest rates, portfolio balances, capital flows, and asset accumulation. The focus then is on the evolution of the nominal ER. That dual role has been at the core of many countries' inconsistent economic programs (see Corden, 1990). 
For instance, pursuing a competitive real exchange rate approach without a separate monetary anchor could lead to higher inflation. On the other hand, using the ER as a nominal anchor to control domestic prices without complementary fiscal and monetary policies could lead to the appreciation of the real ER and create unsustainable trade and current account positions, forcing a devaluation that would then feed into higher inflation and defeat the purpose of using the ER to control inflation.

Many of the economic crises experienced by developing countries over the years resulted from failed economic programs that pursued the dual objectives of competitiveness and inflation control using the ER as a single policy variable in inconsistent macroeconomic programs. In this regard, it is always important to remember the Tinbergen Rule (Tinbergen, 1952), which states that policymakers need to have one instrument for each goal and that, therefore, it would be very difficult for a government to attain two objectives (external competitiveness, as in the real exchange approach, and low inflation, as in the nominal anchor approach) with just one instrument (the ER). A combination of policies is needed to maintain an adequate level in the real ER (more on this later).

Haiti has had at least since the 1990s higher inflation than the Dominican Republic (Chart 5).

\section{Chart 5: Inflation (average \% decade)}

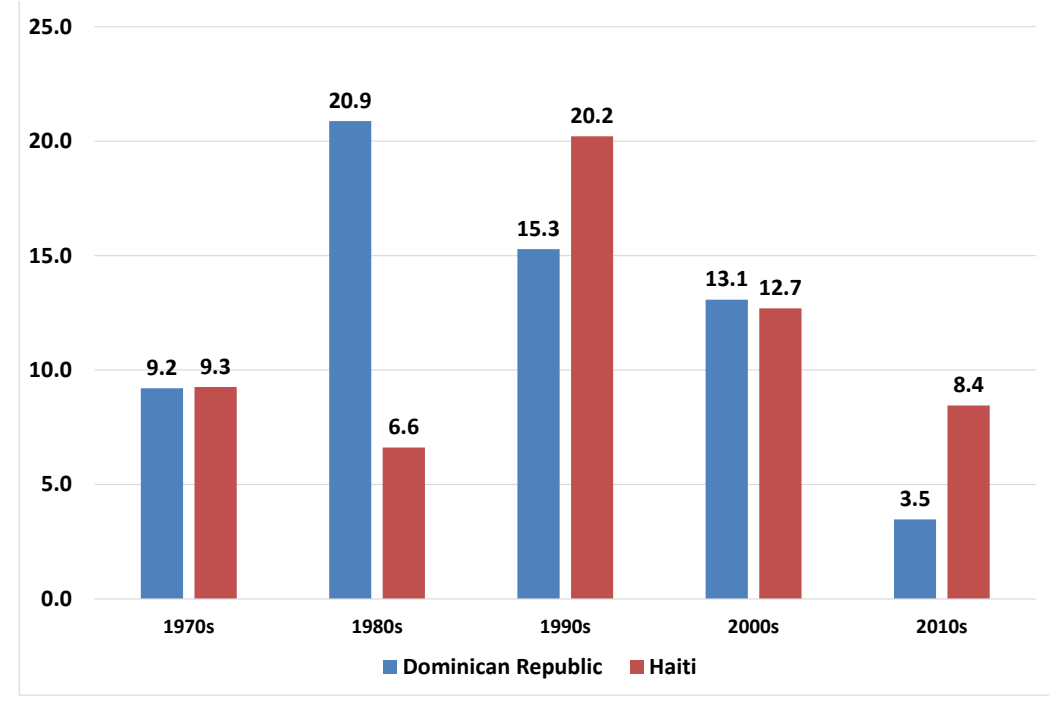

Source: WDI/WB

Therefore, there is a common tendency in countries with high inflation to try to use the ER as a nominal anchor and downplay the need to maintain a competitive RER. Using the ER in stabilization programs usually ends in economic, financial, and currency crises (see Calvo and Vegh, 1999; for an overview of exchange rate-based stabilization schemes and the severe economic, banking, and debt crises experienced by several middle-income countries in the 1980s and 1990s). This concern about higher inflation seems to have been a factor behind the steady appreciation of the RER in Haiti. 
This dual role mentioned has implications for the political economy of exchange rate adjustments as well. For example, producers of traded goods and services generally prefer a devalued exchange rate (depending on the import content of their products), whereas producers of nontraded ones would benefit from a strong currency. However, the expansion of assets and liabilities in dollars adds, both technically and in terms of political economy, a new complexity to the decision to devalue the domestic currency. Debtors in the domestic currency can be helped by devaluations that increase inflation and reduce the real cost of servicing their debt, but the situation is reversed in dollarized countries, where debtors could have their liabilities denominated in foreign currency (see, for instance, Frieden and Stein, 2001).

But even if a country wants to use the ER mainly to maintain competitiveness, it is necessary before to define whether the value targeted is an "equilibrium" one, or whether the ER is "misaligned," and in which direction. These ideas are discussed immediately.

\section{E. EQUILIBRIUM RERS, MISALIGNMENTS, OVERVALUATION AND UNDERVALUATION}

The notion that the RER is "misaligned," either overvalued or undervalued, requires the identification of a benchmark: the equilibrium real exchange rate (ERER). This has been defined as the one that attains both internal equilibrium (meaning that non-tradable markets clear in the current period and are expected to do so in the future with a reasonable price stability) and external equilibrium (when current account balances, now and in the future, are compatible with long-run sustainable capital inflows and balance-sheet equilibrium; see Edwards, 1989; Isard, 2007). However, as implied by the Tinbergen Rule, the ERER will depend on the rest of the relevant policy interventions (particularly monetary, fiscal, and trade ones). A consequence of this combination of factors is that empirical estimations of ERER vary significantly.

Isard (2007) identifies six different approaches that have been utilized to calculate the ERER: purchasing power parity, purchasing power parity adjusted for productivity effects (the Balassa-Samuelson effect), ${ }^{7}$ sustainability of the current account, assessments of the competitiveness of the tradable goods sector, estimates based on a single equation econometrically calculating the equilibrium exchange rate, and assessments based on general equilibrium models. Of the six approaches identified by Isard, the

\footnotetext{
${ }^{7}$ Balassa (1964) and Samuelson (1964) note that if a country increases its productivity in the production of traded goods and services relative to nontraded ones that are larger than those of its trade partners, and if those increases are reflected in domestic prices, then the real exchange rate of that country will appreciate relative to its trade partners.
} 
two most utilized are variants of the sustainability of the current account approach and the single equation estimations approach.

In the latter approach some of the variables considered are in the next Table 2 (from Chudik and Mongardini, 2007).

\section{Table 2: ERER determinants for developing countries}

\section{ERER determinants for developing countries}

The external terms of trade (the ratio of the price of a country's exports over the price of its imports). An improvement in the terms of trade will positively affect the trade balance and thus cause the ERER to appreciate.

Productivity relative to foreign trading partners (proxied by total factor productivity, where available, or relative per capita real GDP). Countries with higher productivity growth in the tradable sector can sustain an ERER appreciation without losing competitiveness.

Government consumption as a share of GDP (relative to that of foreign trading partners). It is assumed that government consumption is biased toward nontradables, increasing their prices, and causing the ERER to appreciate.

The severity of trade restrictions (proxied by variables such exports plus imports as a ratio of GDP). Trade protection to higher domestic prices and thus ERER appreciation.

The ratio of investments to GDP (relative to that of foreign trading partners). Overall impact on the ERER is ambiguous.

Debt service as a share of exports. Higher debt service payments should therefore cause the ERER to depreciate.

Net foreign assets as a share of GDP (a proxy for the country's net external position). Higher values cause the ERER to appreciate.

Aid flows and remittances as a share of exports or GDP. Increases in aid flows causes the ERER to appreciate.

Source: Díaz-Bonilla 2015, modified from Chudik and Mongardini (2007)

Presumably, once the ERER has been estimated, it can then be compared with the actual real exchange rate to determine whether there are important deviations (such as significant under or overvaluation) that requires correction.

Problems of misalignments of the exchange rate are typically related to the dual policy role of ER mentioned earlier as a real price in the real exchange rate approach and as a financial variable in the nominal anchor approach. 
If the estimated value of an equilibrium ER has been determined, should policymakers be equally concerned about the direction of a potential misalignment with respect to that value? In other words, are overvaluations or under-valuations similarly worrying as a policy matter?

The impact of the level and changes in the real exchange rate on net trade of tradable goods and services has been documented empirically (see, among others, Balassa, 1988): in general, an appreciated RER would reduce exports and increase imports (and vice versa for a depreciated RER). This result also applies to agricultural products, both in developed countries (Orden, 1986) and developing ones (for instance, Lamb 2000, in a panel of 14 African countries, finds a positive impact of devaluations on export crop production). And the same is valid for other tradable sectors, such as maquilas and tourism.

A separate question is the impact of over- and undervaluation on economic growth, as well as on other indicators of economic performance. The empirical evidence suggests that overvaluation of the domestic currency beyond levels suggested by fundamentals has negative effects for the economy, while undervaluation appears to be associated with better economic performance, particularly in developing countries.

Several studies have shown that the overvaluation of the real exchange tends to depress economic growth in general (see Dollar, 1992; Rajan and Subramanian, 2009). If a currency is overvalued, then several things seem to happen. First, both wages in dollars and the general costs of investing and producing will increase, reducing domestic and foreign investment in the economy; therefore, growth will decline. Second, increased domestic costs will impact the tradable sector, and the country will end up importing more and exporting less (from agricultural goods to tourism to traded services such as call centers), which will lead to a growing trade deficit. Third, the economy will tend to become more dollarized because informed economic actors will purchase cheap dollars, which end up as deposits in banks (inducing the latter to lend in the same currency). The dollars bought with the strong pesos may also leave the economy as capital flight. Fourth, because trade deficits and capital flight reduce the supply of dollars while demand is high (because the dollar is cheap in pesos), there is an excess demand for dollars, which usually leads governments to impose ER and trade controls and ration the allocation of dollars. This in turn affects the normal functioning of the economy (when, for example, productive activities have to wait for special permits to access the imported inputs needed to operate normally) and generates rent-seeking activities and corruption.

Finally, periods of sustained overvaluation tend to end in sharp devaluations of the ER when the government reaches very low levels of official reserves and no one else is willing to lend dollars (or foreign currency) to that country. As mentioned before, those devaluations usually generate deep and widespread banking and debt crises, depending on the level of dollarization and the external debt accumulated during the period of overvaluation. 
While misaligned ERs in the direction of overvaluation appear to be bad for the economy in general, it has been argued that undervalued exchange rates are associated with higher growth, particularly for developing countries (Rodrik, 2008; Levy-Yeyati and Sturzenegger, 2007; Korinek and Servén, 2010; Haddad and Pancaro, 2010; Berg and Miao, 2010). The reasons given for this result vary.

First, by the RER being undervalued the country avoids the problems linked to overvalued RERs that reduce growth, including the uncertainty as to how a consistent external balance will be achieved (Fischer, 1993), the avoidance of dollarization (the second effect of an overvalued ER mentioned above), and of ER controls (the third effect). Others, such as Rodrik (2008), have emphasized the importance of the tradable sector for productivity and structural transformation (the two key elements for growth) in developing countries. And undervalued RER facilitates the expansion of the tradable sector with the positive effects on productivity and structural transformation, including the learning-by-doing and technological externalities associated with exports. Rodrik (2008) estimates econometrically that undervaluation of the ER is associated with higher growth. Other econometric estimates also find that an undervalued ER stimulates growth (Levy-Yeyati and Sturzzenegger, 2007; Berg and Miao, 2010). However, a policy of undervaluation of the domestic currency cannot be maintained forever, ${ }^{8}$ and eventually the ER will have to revert to an ERER.

If the RER is allowed to appreciate substantially, then eventually a devaluation would follow. Since the 1960s there has been a debate in developing countries about the potentially negative impacts of devaluations as a one-time event (that is, a step adjustment in the ER, as opposed to smooth crawling-peg systems). In general, the immediate impact of the devaluations tends to be negative through a variety of channels. In particular in dollarized economies the impact on the private and public sector indebted in dollars (a balance-sheet effect), could generate bankruptcies and defaults, eventually leading to banking and financial crises (and sometimes the banks were indebted abroad in dollars as well). Once the banks are affected, the crucial functions they perform as providers of liquidity for the functioning of the economy get impaired and economic activity may grind to a halt, with a sharp contraction of the GDP.

But econometric estimates also show that in the medium-term growth resumes fueled by tradables (Kamin and Klau, 1998; Gupta, Mishra, and Sahay, 2003). Also the question is what is the point of comparison: whether it is before and after a devaluation (as it was basically the case in the studies mentioned), or whether it should consider the counterfactual without devaluation (see for instance Pauw, Dorosh, and Mazunda (2013), who found that for Malawi's economy and welfare in 2011 and 2012 it would have been better to devalue early, instead to wait until the crisis forced the devaluation).

\footnotetext{
${ }^{8}$ See the discussion in Díaz-Bonilla, 2015.
} 
In summary, devaluations seem to have negative impacts in the short term, particularly for countries with open capital accounts and dollarized banking systems. The policy lesson, however, is not to reject devaluations but to avoid being placed in the situation where there is not much else that can be done to restore macroeconomic balances, and the resulting devaluation ends up being sharper and more disruptive than if the ER had been allowed to move earlier in order to stay closer to equilibrium values. Also, when a country is hit by negative shocks, it is better to correct the ER earlier rather than to let imbalances accumulate.

It is also true that devaluations to restore equilibrium values also affect consumption, with potentially negative impacts on poverty and food security, particularly if changes in the ER lead to a generalized economic crisis. But again, the conclusion is the need to avoid the overvaluation of the ER, which then leads to abrupt and damaging adjustments in the parity. Concerns about the poor and vulnerable should make avoiding macroeconomic crises the first policy priority, given the devastating effects they may have. But, once the ER is overvalued, delaying the adjustment because of concerns about the poor and vulnerable tends to increase

the imbalances and force even more damaging adjustments later. Therefore, it is better to correct the ER earlier than later. In any case, it is crucial to implement safety nets for the poor and vulnerable, including food stamps, food-for-work, school lunches, and supplementary feeding for mothers and infants. Those programs should be designed and deployed during calmer times, so they can then be expanded during periods of economic distress.

Haiti should avoid overvaluation of the ER and maintain a true crawling peg that devalues the nominal ER in line with inflation. This will require to apply stricter fiscal and monetary policies to control inflation.

Still it can be argued that the appreciation of the gourde is a result of fundamental forces, and therefore is an equilibrium result. For instance, IMF (2007) argues that in their estimates at that time that it cannot be said for sure whether the RER is appreciated against its estimation of the equilibrium RER at that time, particularly considering the large inflow of remittances to Haiti, which is expected to appreciate the RER. We look at this topic in the next section

But before that it is useful to note another point made by IMF (2007), that argues that such appreciation goes against the expected trend, both theoretically and empirically shown, that RER appreciates with increases in real GDP per capita and productivity. But, in fact, GDP per capita in Haiti has declined since the 1980s as shown in Chart 6, where the Dominican Republic is included as comparison. 


\section{Chart 6: GDP per capita (US 2010 constant)}

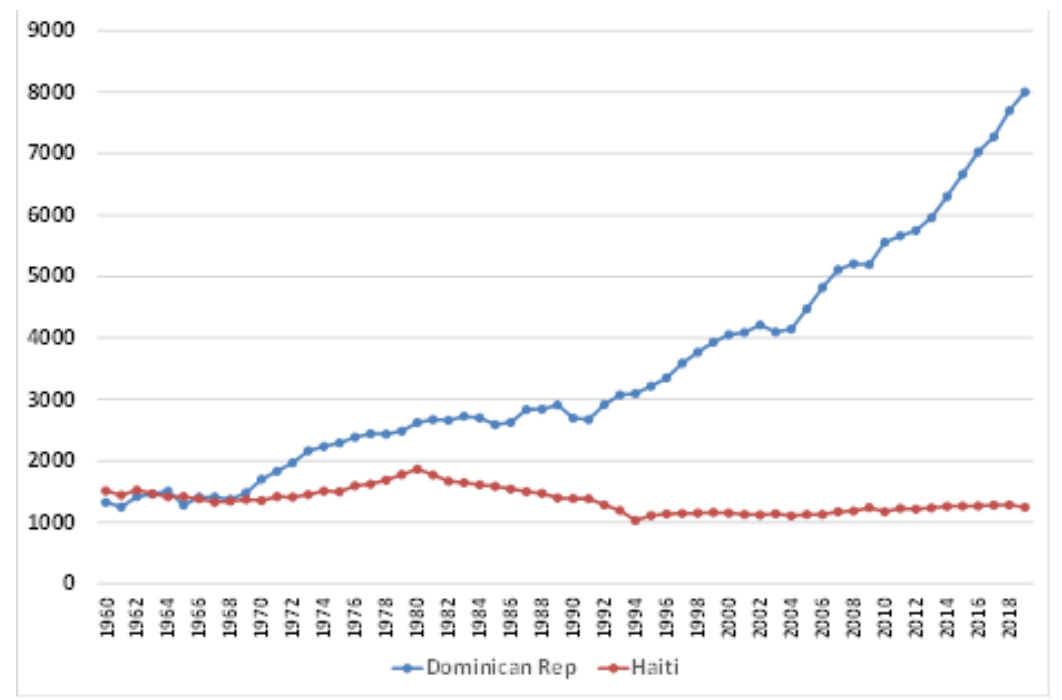

Source: WDI/WB

Another question to notice is whether it is expansion of money supply which eventually leads to devaluations. This interpretation is not supported: a Granger test of causality (see Table 3 ) shows that the null hypothesis that growth in money does not cause a devaluation cannot be rejected, while the reverse is rejected.

Table 3: Test of Granger Causality

Null Hypothesis:

MONEYGRTH does not Granger Cause DEVALUATION

DEVALUATION does not Granger Cause MONEYGRTH

\section{Obs}

29

1.99296

4.68351
Prob.

0.1582

0.0192

Source: Authors 


\section{F.REMITTANCES}

Remittances received by Haiti have been in a constant growth since 1996 , reaching a high of $\$ 3,274$ million dollars in 2019 (Chart 7). Haiti has the largest ratio of remittances to the GDP in Latin-America and the Caribbean ${ }^{9}$ and one of the largest in the world. ${ }^{10}$

\section{Chart 7: Migrant remittance inflows (US\$ million)}

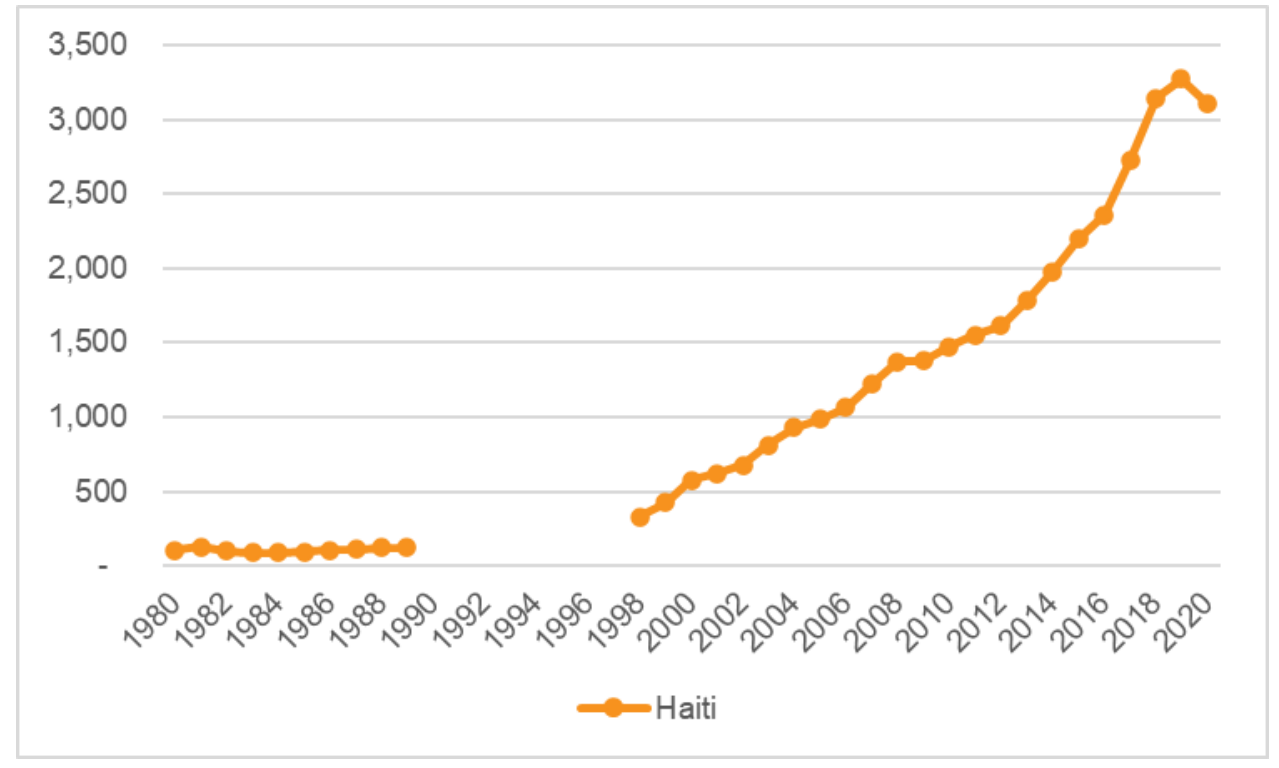

Sources: Authors elaboration, World Bank Inward Remittances Inflows.

COVID-19 is estimated to have had a detrimental effect in the remittances flow, since many labor markets where Haitian migrants work have been shut down due to the pandemic. World Bank estimates that remittances inflows to Haiti have shrunk 5\% due to the COVID-19 crisis by October of 2020. With the US economy reopening that decline will most likely be reversed.

At the household level, it is estimated that a third of the Haitian households receive remittances, with this percentage being higher in urban households (35\% of those families) than in rural settings $(20 \%$ of the households). ${ }^{11}$ These funds can represent up to $20 \%$ of the household income and is mainly destined to food, education and health purchases.

\footnotetext{
${ }^{9}$ KNOMAD, 2020. COVID-19 CRISIS THROUGH A MIGRATION LENS Migration and Development Brief 32 April 2020.

${ }^{10}$ World Bank inward Remittances Inflow database.

${ }^{11}$ UN, 2020. Évaluation Socioéconomique de l'Impact du COVID-19 République d'Haïti.
} 
Most of the Haitian migrants are found throughout the Americas, especially in the United States. By $2018^{12}$, there were almost 700,000 Haitians living in the US, most of them having arrived before 2010, thus only 55,000 have been granted Temporary Protected Status due to migrating a consequence of the 2010 earthquake. Significant populations of Haitian migrants can be also found in the Dominican Republic (491,000), Canada (100,000), France $(82,000)$ and Chile $(69,000)$. About $50 \%$ of the remittances received by Haiti come from the US, and $20 \%$ from the Dominican Republic. ${ }^{13}$

Remittances in Haiti have long worked as a safety net for its residents; calculations of the ECLAC show that in 2019, Haiti's GDP dropped $0.7 \%$, but an increase in remittances softened the blow to the local economy..$^{14}$

In the US, $61 \%$ of the residing Haitians are naturalized citizens ${ }^{15}$ and almost all of them achieve this status as immediate family members of US Citizens of family sponsorships, highlighting the strengths of family networks in the US and back home. Given that pandemic relief efforts often did not cover undocumented migrants, it is expected that the income of this group to have faltered even more than the documented residents.

According to publications from The Dialogue ${ }^{16}$, overall, $35 \%$ of the migrants in the US live with less than $\$ 20000$ a year. ${ }^{17}$ Estimations suggested that a $4.5 \%$ job loss among all migrants in the US would imply for Haiti a decrease of almost a third of the remittances compared to those sent in 2019. By November 2020 , only $7 \%$ of household respondents of a survey conducted by the UN reported receiving remittances. $^{18}$

Remittances have proved to be a lifeline to many vulnerable Haitian households, but the Haitian government recent requirement to sell $30 \%$ of the remittances received at an unfavorable official exchange rate lower than the parallel exchange rate would impact that source of incomes. ${ }^{19}$

The data mentioned suggest that the positive effects on households' incomes need to be considered along with the macroeconomic impacts on overall growth, employment, and international competitiveness, as discussed immediately.

\footnotetext{
${ }^{12}$ https://www.migrationpolicy.org/article/haitian-immigrants-united-states-2018

${ }^{13}$ FEWSNET, 2020. Haiti Food Security Outlook. June 2020 to January 2021. https://reliefweb.int/sites/reliefweb.int/files/resources/HT FSO June January June30 Final EN.pdf

${ }^{14}$ The Dialogue, Migrants and the Impact of the COVID-19 Pandemic on Remittances, May 2020.

${ }^{15}$ Migration policy, ibidem.

${ }^{16}$ The Dialogue, 2020. MIGRANTS, REMITTANCES, AND COVID-19 Remittance Behavior and Economic and Health Vulnerabilities.

${ }^{17}$ OECD, 2020. Haitian Families and Loss of Remittances During the COVID-19 Pandemic. Development Matters, May 2020.

18 UN 2020, ibidem.

${ }^{19}$ UN 2020, ibidem.
} 


\section{G. REMITTANCES, FOREIGN AID, AND THE RER}

In the case of Haiti, as for other low-income developing countries, it is important to look at the impact of foreign aid and remittances on the ER. Rajan and Subramanian (2006) estimated econometrically that impact. They found that foreign aid appeared associated with overvaluation of the real exchange rate in their sample of developing countries, with negative effects on the growth rate of exporting industries, particularly those that are in labor-intensive sectors. Remittances, on the other hand, did not seem to lead to the same effects: they conjectured that this was so in part because of the nature of the goods and factors on which remittances are spent and in part because countries that already have appreciated exchange rates appear to receive fewer remittances.

On the other hand, Lopez, Molina, and Bussolo (2007) argue that when remittance flows are large relative to the size of the recipient economies, they lead to a real exchange rate appreciation and a loss of competitiveness in the tradable sector. Therefore, it would seem that the continuous appreciation of the gourde would be in line with the "fundamentals": to the extent that Haiti has been receiving increasing amounts of remittances, then the appreciation, in this line of analysis, would follow.

Therefore, the usual recommendation is to try to ensure that those flows are invested in areas such as productive infrastructure, technology, and human capital, all of which raise the productivity of tradable sectors and help outweigh the negative impact of the potential overvaluation that those flows may generate. But as the money from the remittances belongs to the families, they will use it for the expenditures and activities they prefer. Those would not necessarily be the uses mentioned before that would improve competitiveness, except if those flows, or part of them, are taxed away (more on this later; those taxes have been usually discouraged with the argument that these are lifelines for poor people; however, it should be noticed that evidence does not support the idea that the poorest segments of the society are the main recipients of remittances).

However, the comparison with the Dominican Republic offers another perspective on the impact of remittances on the appreciation of the RER.

Chart 8 shows remittances in millions of dollars to both countries. 


\section{Chart 8: Remittances in millions of current dollars}

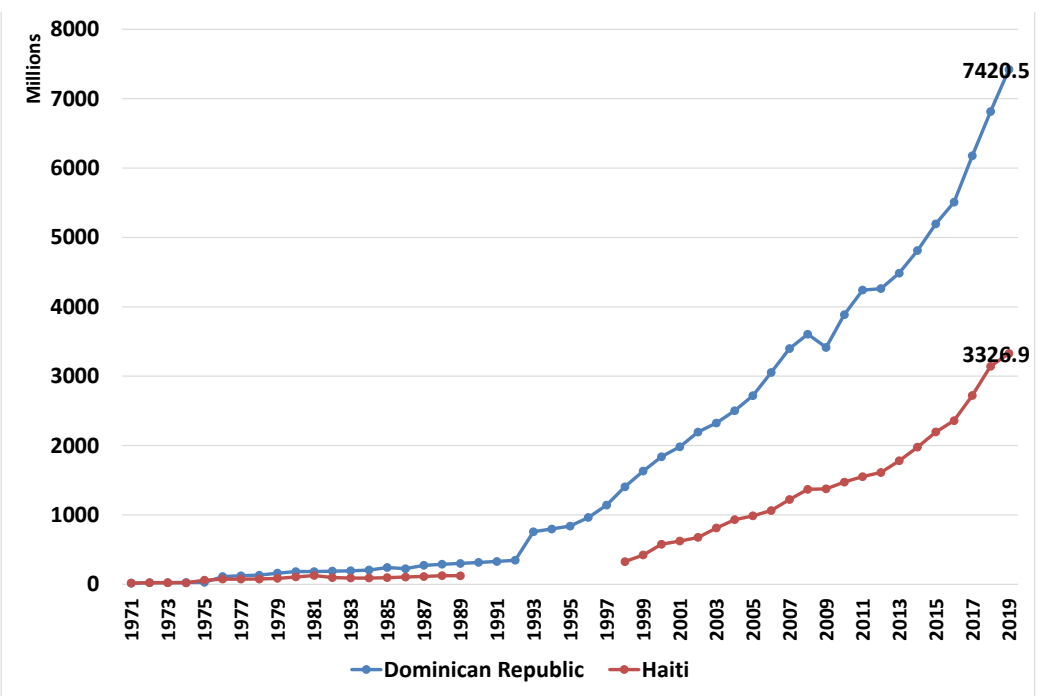

Source: WDI/WB

Clearly the Dominican Republic receives more than two times the value of remittances when compared with Haiti, but, as shown before, after the devaluation of the 1980s that country nonetheless managed to maintain a relatively stable RER or at least not an appreciating one (by adjusting more frequently the nominal ER), as in the case of Haiti. In fact, there is a depreciation in the RER of the peso since the mid-2000, a period of strong increases in remittances.

Still, it could be argued that the value of remittances cannot be compared without reference to the size of the economy (total GDP). Chart 9 shows remittances as percentage of the GDP.

\section{Chart 9: Remittances as \% of GDP}

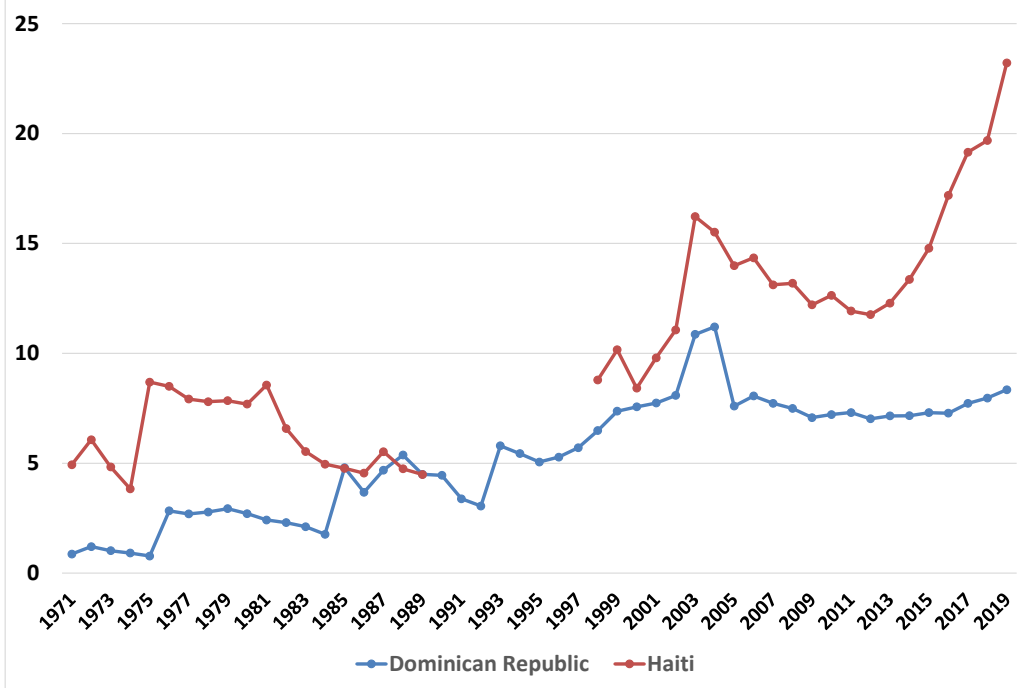

Source: WDI/WB 
It is true that as a percentage of the GDP remittances are more important in Haiti than in the Dominican Republic, but this reflects the stagnation of the Haitian economy (for which it could be argued the appreciation of the gourde has been a contributory factor) and not the size of remittances.

Another way to provide a proper scaling of the importance of remittances in both countries is to compare the amount of dollars received per capita. Considering that Haiti also receives foreign aid, the next Chart 10 shows the per-capita value of remittance and international grants (as reflected in balance of payment statistics).

\section{Chart 10: Remittances and Grants per capita}

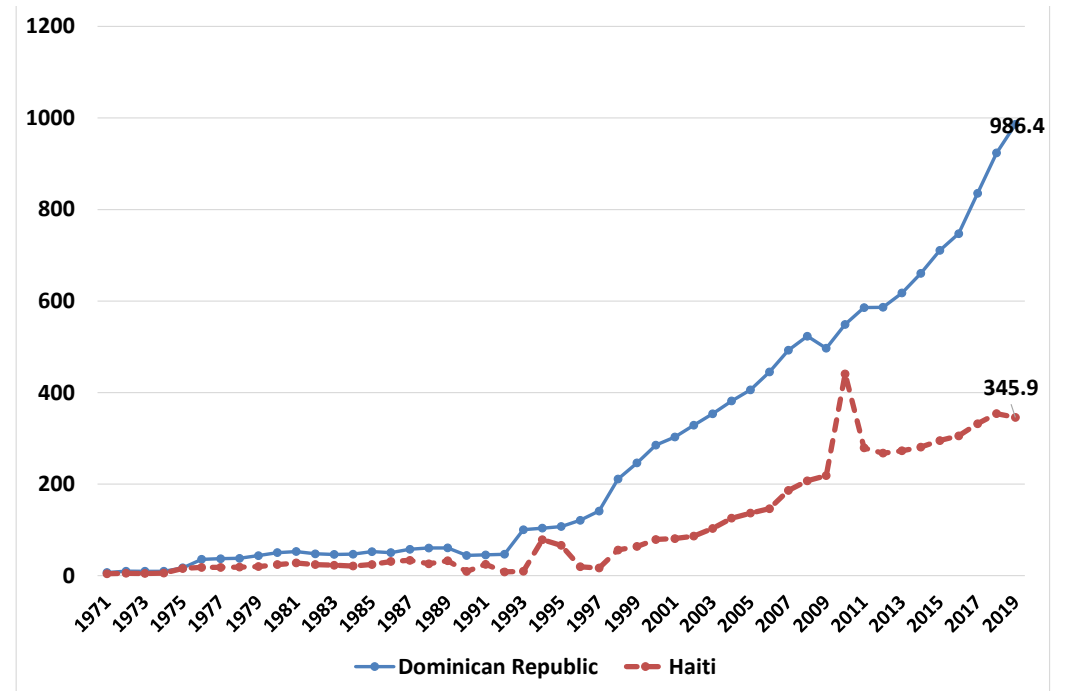

Source: WDI/WB

Dominican Republic even counting foreign aid (grants), receives an amount of dollars per capita significantly larger than Haiti due to the remittances (the Dominican Republic receives less of foreign aid than Haiti).

Therefore, even with that inflow of dollars from abroad, the Dominican peso did not experience the same appreciation shown by the gourde. This is important because, as mentioned several times, appreciation of the RER is associated with less growth related to less competitiveness for all tradables (maquila industry, agriculture and tourism, to name the most important for Haiti).

If remittances then do not seem to explain the level of appreciation of the gourde, what other factors may influence that outcome? 


\section{H. DOLLARIZATION AND FEAR OF FLOATING}

The experience of Dominican Republic suggests the need to look at more than remittances and foreign aid to explain the continuous appreciation of the gourde. It may be related to what was been called "fear of floating" (Calvo and Reinhart, 2000), i.e. the concerns that policy makers may have regarding adjusting the NER, even in the presence of continuous appreciations.

This is usually related to a combination of factors. One aspect is "dollarization," or the generalized use of a foreign currency in the economy, even when retaining a national currency. There are different degrees of that phenomenon depending on the percentage of transactions in which foreign currency is present: for example, deposit dollarization, lending dollarization, external debt (private and public), types of goods and services in which the pricing and the payments are denominated in dollars, etc.

Haiti is a country with a high level of dollarization (IMF, 2020a). Chart 11 shows the percentage of foreign currency deposits on total deposits, and the percentage of foreign currency loans on total loans (from IMF, 2020a)

\section{Chart 11: Dollarization levels}

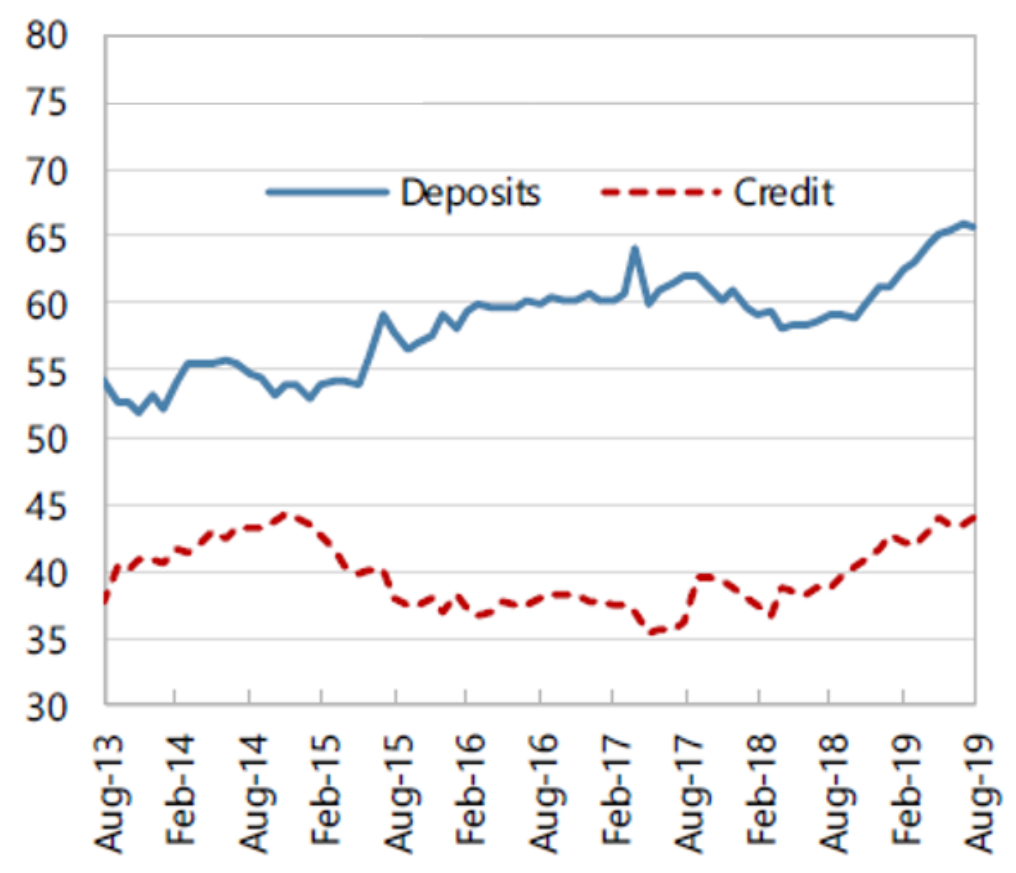

Source: IMF, 2020a 
Chart 12 places Haiti in comparison with other countries that are highly dollarized and also in contrast with the Dominican Republic, using only dollarization of deposits (foreign deposits as percentage of a broad monetary aggregate, M3).

\section{Chart 12: Foreign Deposits \% M3}

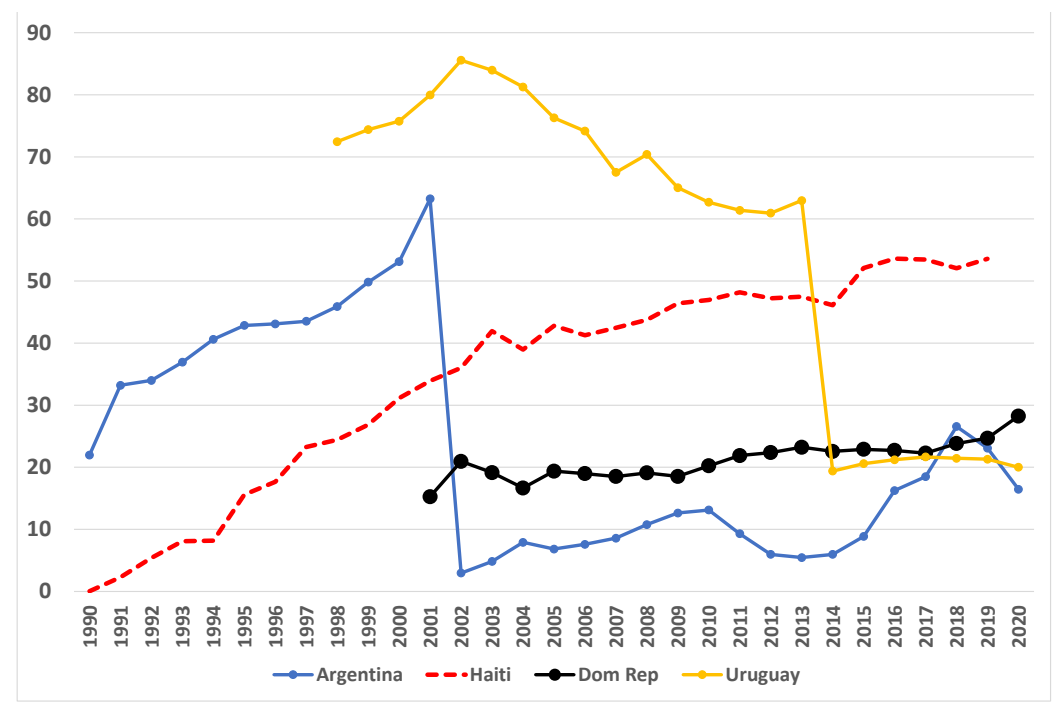

Source: World Development Indicators, WB

After being more dollarized than Haiti, both Argentina and Uruguay underwent a strong processes of de-dollarization, placing them now below Haiti and more in line with the Dominican Republic. Haiti, on the other hand has continued to increase its levels of dollarization, which are now, by this measure, twice the levels of the comparators in the chart.

The very high levels of dollarization in Haiti constrain the possibility of using the NER to adjust to shocks, because the impact on the banking system of those adjustments need to be considered. A devaluation (and the expectation of a devaluation) would affect directly loans in dollars and deposits in dollars with the possibility that firms can go bankrupt, and depositors may decide to withdraw their dollar deposits when fearing a currency crises, asking for physical dollars (perhaps to transfer them abroad or to hide them under the mattress). This would require that banks (1) use their own reserves; (2) ask for support from the central bank, which, using its own reserves, might lend foreign currency to the banks to cover the withdrawals (but the central bank may not have enough reserves to counter that run on dollar deposits); or (3) borrow abroad (but in an actual or expected crisis, there will be no willing 
foreign lenders to the banks). ${ }^{20}$ The result would be a banking/financial crisis and a deep economic recession, given the central role of the banks in the payment system.

Besides dollarization, another factor to consider when evaluating the room a country has to adjust its ER (and therefore the "fear of floating") is the level of control of transactions in foreign currencies (the exchange rate market): i.e. whether the transactions in foreign currency related to trade, financial, and other international flows (such as remittances) must go through some specified governmental channels and follow some strict regulations, being exchanged in domestic currency at official rates.

The stronger the governmental controls on foreign exchange operations the less is the government's "fear of floating" because authorities would not be as concerned about violent movements in ERs as a result of panicked reactions by private actors.

The level of controls varies depending the type of operations included in those official channels and regulations. In general, Haiti has maintained very few controls on foreign currency transactions (see Annex 1 with IMF information about Haiti). However, there were recent changes related to the liquidation of remittances, which were among the causes for the new volatility in ER.

Without controls on the access and use of dollars (that is, no controls in current and capital accounts of the BOP), then it happens what has been called "the impossible trinity," linking monetary aspects, capital flows, and the exchange rate. This impossibility principle implies that if a government has decided to eliminate restrictions in current and capital account transactions (first policy choice), it can have only one independent policy decision between the level of the exchange rate (second policy choice) and a separate monetary policy (third policy choice) at the same time (see Díaz-Bonilla, 2015, for a more detailed discussion).

Without capital controls, banks and the private sector may borrow or lend abroad. Banks can offer dollar loans by borrowing abroad, and if they are hit by devaluations, as happened in the case of several Asian countries during the 1997-1998, there is a systemic crisis. Also, the nonbanking private sector may be borrowing in foreign currency directly (without going through the banking system), which may pose its own risks for the economy (even if not intermediated by the banking system).

\footnotetext{
${ }^{20}$ The banking and financial crises in several developing countries in the last decades also showed that international banks from advanced economies would not necessarily supply dollars in support of their subsidiaries operating in developing countries in the middle of such crises.
} 


\section{EXCHANGE RATE POLICIES}

Considering all the discussion before, what ER policy should Haiti follow? The debate about the real exchange approach and the nominal anchor approach are also related to the discussion about the advantages and disadvantages of fixed versus flexible regimes of the ER.

\section{a. Fixed versus flexible ${ }^{21}$}

A perennial policy debate has been the costs and benefits of fixed and flexible ER regimes, but in fact there is a range of possibilities. What is the better ER regime depends on

1. what the meaning of "better" is: answers may differ if the policymaker is concerned more about inflation, or growth, or the probability of crises, or, in more sophisticated analyses, what general welfare function is maximized;

2. how rigid are prices and wages and whether there may be some other nominal rigidities in the economy;

3. how ER policy is coordinated with the whole macroeconomic policy framework, in particular the type of monetary policy implemented and the fiscal position;

4. whether the capital account is open, closed, or something in between (that is, the type of constraints that can affect transactions in asset markets, segmenting the country from world markets); and

5. what the nature of the shocks is: whether they come from the real economy (say, a drought) or whether they are nominal disturbances (such as increased inflationary pressures in a trading partner).

Table 4 shows a summary of benefits and costs across different dimensions

${ }^{21}$ The next sections follow Díaz-Bonilla, 2015 


\begin{tabular}{|c|c|c|c|}
\hline ER & Inflation & Growth and volatility & Crisis \\
\hline Fixed & $\begin{array}{l}\text { It may enhance monetary policy } \\
\text { credibility and lower inflation if } \\
\text { the fixed ER is expected to last. } \\
\text { But individual emerging mar- } \\
\text { kets are less likely to be able to } \\
\text { import credibility only through a } \\
\text { fixed ER (except by becoming } \\
\text { members of a monetary union, } \\
\text { such as the European Union). } \\
\text { Moreover, inflation may be just } \\
\text { repressed temporarily, but then } \\
\text { reappear and lead to overval- } \\
\text { ued domestic currencies and } \\
\text { sudden devaluation. }\end{array}$ & $\begin{array}{l}\text { It may reduce transactions } \\
\text { costs and help increase trade. } \\
\text { More trade may lead to im- } \\
\text { proved productivity and higher } \\
\text { growth. } \\
\text { It may also reduce domestic in- } \\
\text { terest rates and uncertainty, } \\
\text { also raising investment and } \\
\text { growth. } \\
\text { In general, it works better when } \\
\text { shocks are nominal. } \\
\text { On the other hand, it may in- } \\
\text { crease volatility in the presence } \\
\text { of real shocks and nominal ri- } \\
\text { gidities, which negatively af- } \\
\text { fects growth. }\end{array}$ & $\begin{array}{l}\text { Higher risk of speculative at- } \\
\text { tacks against currency, espe- } \\
\text { cially when exposed to volatile } \\
\text { capital flows. Susceptibility to } \\
\text { generalized debt and banking } \\
\text { crises when the fixed ER has to } \\
\text { be sharply adjusted in the face } \\
\text { of shocks and macroeconomic } \\
\text { imbalances. }\end{array}$ \\
\hline Flexible & $\begin{array}{l}\text { May lead to higher average in- } \\
\text { flation if the macroeconomic } \\
\text { and institutional frameworks are } \\
\text { weak. } \\
\text { However, with stronger institu- } \\
\text { tions and financial sectors the } \\
\text { inflationary performance can be } \\
\text { adequate. }\end{array}$ & $\begin{array}{l}\text { It may facilitate smoother ad- } \\
\text { justment and fewer distortions } \\
\text { following real shocks (as op- } \\
\text { posed to nominal ones), there- } \\
\text { fore increasing growth. } \\
\text { On the other hand, real ex- } \\
\text { change rate volatility may re- } \\
\text { duce trade and investments, re- } \\
\text { ducing growth. }\end{array}$ & $\begin{array}{l}\text { Lower risk of currency and } \\
\text { banking crises. }\end{array}$ \\
\hline
\end{tabular}

\section{b. More complex classifications}

But ER policy regimes do not fall into these two rigid extremes. In fact the IMF uses a more detailed classification depending on what actual o de facto arrangement a country is using, as identified by IMF staff, which may differ from their officially announced arrangements. The classification ranks exchange rate arrangements on the basis of their degree of flexibility and the existence of formal or informal commitments to exchange rate paths. Table 5 from IMF 2020b shows the current classification, with four main groups and ten categories within those groups. 
Table 5: ER policy regimes

\begin{tabular}{|c|c|c|c|c|c|}
\hline Type & Categories & & & & \\
\hline Hard pegs & $\begin{array}{l}\text { Exchange arrange- } \\
\text { ment with no sepa- } \\
\text { rate legal tender }\end{array}$ & $\begin{array}{l}\text { Currency board ar- } \\
\text { rangement }\end{array}$ & & & \\
\hline Soft Pegs & $\begin{array}{l}\text { Conventional } \\
\text { pegged arrangement }\end{array}$ & $\begin{array}{l}\text { Pegged Exchange rate } \\
\text { within horizontal bands }\end{array}$ & $\begin{array}{l}\text { Stabilized } \\
\text { arrangement }\end{array}$ & Crawling peg & $\begin{array}{l}\text { Crawl-like } \\
\text { arrangement }\end{array}$ \\
\hline $\begin{array}{l}\text { Floating regimes (mar- } \\
\text { ket determined rates) }\end{array}$ & Floating & Free floating & & & \\
\hline Residual & $\begin{array}{l}\text { Other managed ar- } \\
\text { rangement }\end{array}$ & & & & \\
\hline
\end{tabular}

Note: the methodology became effective February 2, 2009, and reflects an attempt to provide greater consistency and objectivity of exchange rate classifications across countries and to improve the transparency of the IMF's bilateral and multilateral surveillance in this area.

Source: IMF, 2020b

Haiti's ER regime is classified as "Crawl-like arrangement" but the note for Haiti reads "The country maintains a de facto exchange rate anchor to the US dollar." That is Haiti uses the ER more as a nominal anchor and not as an instrument of international competitiveness, which in the context of persistent inflation has led to the appreciation of the RER, and eventual step-wise devaluations when reserves are low. This has generated more volatility in the RER as shown in Chart 13, comparing the coefficient of variation of the RER in Haiti and the Dominican Republic since the 1990s.

\section{Chart 13: Coefficient of Volatility}

\section{Coefficient of Volatility}

0.25

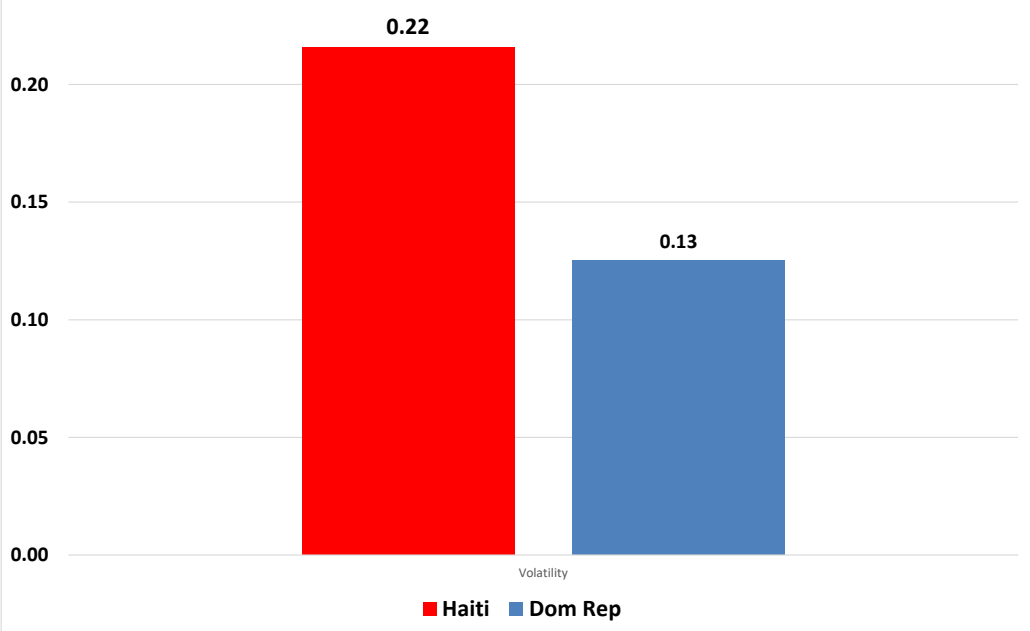

Source: authors with data from WDI/WB 
The RER in Haiti is almost twice as volatile as in the Dominican Republic, and the recent strong appreciation has made that variable even more volatile. This is one of the paradoxes of regimes that use ER as nominal anchor when other variables are not properly aligned: they end up having more volatility in the ER because the sharp adjustments needed to correct the increasing loss of competitiveness due to the overvaluation of the domestic currency.

Exchange rate variability is important because various studies have shown the negative impact of exchange rate variability on production, investments, and exports in general (Bleaney and Greenaway, 2001), and for the agricultural sector in particular (for instance, Cho, Sheldon, and McCorriston, 2002). ${ }^{22}$

If Haiti would have followed a true crawling peg arrangement to try to maintain the RER more in line with inflation there would have been less instability.

Therefore, Haiti has probably had the less favorable combination for growth, employment, and inflation: an appreciating RER that from time to time has to adjust somewhat sharply, which then leads to more volatility. Following a crawling-peg with inflation would have been better in terms of growth, employment, and also for inflation, by stabilizing the demand for gourdes and reducing dollarization.

\section{c. Exchange rate regime and monetary regimes}

The empirical studies discussed in Díaz-Bonilla, 2015 showed different effects of ER regimes depending on the categories of countries: advanced, emerging, and lower income. Those country categories, however, may just serve as an imperfect proxy for the combination of several key characteristics, such as the ER regime, the monetary regime, the extent of capital controls, and the level of dollarization in the economy. In that sense, it would be more relevant to classify countries using those dimensions rather than simply using the more general country categories mentioned (for instance, utilizing indicators of capital account openness such as the one discussed in Chinn and lto 2008, dollarization in Reinhart, Rogoff, and Savastano 2003, or other similar indexes).

Table 6 shows a cross-classification of ER and monetary regimes using the information from the IMF's Annual Report on Exchange Rate Arrangements and Exchange Restrictions (IMF 2020b).

\footnotetext{
${ }^{22}$ A related topic is the volatility of export earnings and the impact on investment and growth. Dawe (1996) estimated a properly specified measure of export volatility for 85 countries during 1965-1985 and found that instability seems to increase domestic savings and lead to more investments, but the efficiency of that investment is impaired by the uncertainty. Given that the second effect seems to dominate, export volatility tends to have a negative influence on economic growth.
} 
Table 6: Exchange rate and monetary policy regimes

\begin{tabular}{|c|c|c|c|c|c|}
\hline Exchange rate & $\begin{array}{c}\text { ER } \\
\text { anchor }\end{array}$ & $\begin{array}{l}\text { Monetary } \\
\text { aggregates }\end{array}$ & $\begin{array}{l}\text { Inflation } \\
\text { targeting }\end{array}$ & Other & Total \\
\hline Hard peg & & & & & 24 \\
\hline Conventional peg and stabilized arrangements & & & & & 67 \\
\hline $\begin{array}{l}\text { Crawling pegs, crawl-like pegs, pegged ER with horizontal } \\
\text { bands, and other managed approaches }\end{array}$ & & & & Haiti & 35 \\
\hline Floating & & & & & 35 \\
\hline Pure floating & & & & & 31 \\
\hline Total & 80 & 26 & 41 & 45 & 192 \\
\hline
\end{tabular}

Source: IMF (2020b).

As noted before in terms of ER regimes Haiti was classified under crawl-like pegs, but with a note that suggests that Haiti maintains a harder peg ("a de facto exchange rate anchor to the US dollar"), and this combines with a monetary regime that is sui-generis (classified under "Other").

Considering the number of developing countries in the different cells, Díaz-Bonilla, 2015 distinguishes at least four types of situations to discuss macroeconomic policies in greater detail, as follows.

\section{Type 1}

This type includes countries with ER as monetary anchor and using hard ER pegs linked to the use of a foreign currency as the domestic money or currency boards. Their ERs may be linked to the US dollar, the euro, or some other currency. Basically, there is no independent role for the monetary and exchange policies. They need to work with the other instruments of macroeconomic (fiscal, trade, and income policies) and microeconomic/sectoral policies to maintain both inflation under control while not losing competitiveness.

\section{Type 2}

These countries use the ER as the monetary anchor and have what the IMF calls conventional pegs or stabilized arrangements (that is, the ER stays close to a stable central rate). Several of these countries have capital controls and low or no dollarization and therefore have more room to pursue independent monetary policies, even with a fixed ER. Still, they need to articulate fiscal, monetary, ER, and other policies affecting nominal variables so that the levels of inflation do not lead to overvaluation of their 
currencies. Devaluations, however, will not trigger the same type of debt and banking crises as in countries with more open capital accounts and dollarized economies.

\section{Type 3}

These countries use money targets (or the "other" category, which uses multiple instruments) and crawling pegs/softer pegs. This group is very heterogeneous, and it would be necessary to distinguish at least those countries with capital and other controls on international transactions, and low or no dollarization (Type 3a), and those with low or no controls on capital and external transactions and high dollarization (Type 3b). Haiti is in this last category. Countries in Type 3a can expand money supply and manage the ER peg tightly at the same time, while those with open current and capital accounts and dollarization (Type 3b) are restricted in their choices. Haiti and countries in that latter category would need to utilize a monetary framework and other non-ER policies that maintains inflation aligned with their trading partners or adjust the ER frequently in an active crawling peg (avoiding the use of the ER as a nominal anchor), while using regulatory and other measures to try to "de-dollarize" the economy, and microeconomic/sectoral policies for competitiveness.

\section{Type 4}

These countries use an "inflation-targeting" monetary regime and have a floating or free-floating ER regime. These are higher-middle-income developing countries, and, more commonly, developed countries. However, many of the developing countries in this category have resorted to a variety of monetary instruments and not only the short-term interest rates as monetary instruments, and they have paid attention to the behavior of the ER. Therefore, the IT framework, as utilized in practice, has been more eclectic than in the original and more theoretical formulations.

\section{J. CLOSING OBSERVATIONS}

Haiti has shown a long process of appreciation or overvaluation of the RER. It seems not to be supported by the variables that would justify that appreciation as a consequence of "fundamentals," to the extent that neither the size of the government nor increases in GDP are relevant. Remittances are high but not larger in per capita terms compared to Dominican Republic, which maintained its RER more stable and competitive. The appreciation vis-à-vis the US dollar and the Dominican peso have been particularly acute in 2020 and although somewhat reverted lately, continued until the last data available. We also run an equation attempting to estimate the equilibrium RER, and although more work would be needed, we did not find a statistically significant correlation between the RER and remittances and foreign aid (per capita), GDP per capita (which was also of the wrong sign, as in IMF, 
2007) and the terms of trade (which showed improvements from the early 2000s and peaked around the start of 2010 s but declined afterwards). ${ }^{23}$

It may be the case that the data does not capture other incoming flows, some of them illegal, that may have influenced the appreciation of the RER. Also, we looked briefly to the resources entering the Haitian economy through the operations of MINUSTAH. Unfortunately, there is no collected data on a single place, and, more relevant, it would require a detailed budget analysis to determine how much was spent in Haiti (the only component that would affect the RER) and how much was spent outside the country. This topic may need a more detailed analysis, to determine the potential role on the appreciation of the RER. However, those operations have ended in late 2017 and the subsequent UN operations have been smaller, and there has been a strong appreciation in the last months.

Still, the presence of numerous international staff in Haity should have an impact on the prices of nontradables, appreciating the RER. Therefore, as argued later, those activities and resources from international and bilteral agencies must be focused as much as possible on programs that directly improve production, employment, competitiveness, and social conditions for the people of Haiti, with an adequate balance regarding programs that focus on issues of governance, which, although very important, do not improve immediately the livelihoods of the population.

As noted overvalued exchange rates tend to depress growth, lead to recurrent trade and financial crises, and promote dollarization, which generates "fear of floating" and, if adjustments in NER happen, lead to deeper crises, accompanied by increases in poverty and deterioration of food security.

Therefore, the best way of sustaining growth, alleviating poverty, and improving food security is to avoid the overvaluation of the ER and the related imbalances. Also, when negative shocks happen that require adjustments in the $E R$, it is better to do it early rather than let imbalances grow, which will need more drastic measures later. The best way to protect the poor and vulnerable is through social safety nets that can be expanded during emergencies.

Problems of misalignments of the exchange rate are typically related to the dual policy role of ER, already mentioned, as a real price in the real exchange rate approach, which emphasizes trade and competitiveness issues, and as a financial variable in the nominal anchor approach, which uses the nominal exchange rate to control inflation and/or is concerned about the assets and liabilities of domestic actors, particularly the banking system. Many economic crises in developing countries have resulted from failed economic programs that did not properly articulate that dual role. Policymakers need to have one instrument for each goal; it would be very difficult for a government to attain two objectives (external competitiveness, as in the real exchange approach, and low inflation, as in the

\footnotetext{
${ }^{23}$ Other variable to be considered in a more detailed exercise is net foreign assets (that improved also somewhat in the last years).
} 
nominal anchor approach) with just one instrument such as the ER. Therefore, it is necessary to define the exchange rate, monetary, fiscal, and trade policies through a consistent economic program. For Haiti it would be better to use the real exchange approach focusing the ER on growth, employment and competitiveness, and use other instruments as nominal anchors.

Economic development will benefit from a managed float combined with a monetary framework that keeps inflation under control and regulatory measures that eliminate currency mismatches in the banking system and excesses in credit growth and appreciation of certain assets such as land, houses, and the stock market. Regulations must ensure that banks are not affected by currency exposures (such as lending in a foreign currency to domestic economic agents that have incomes in the national currency); that they apply adequate loan-to-value ratios for their lending operations; and that they have enough capital and liquidity to confront difficult times. Countries should try to limit and reduce dollarization (although there are few examples of such processes having been reverted) by keeping inflation under control and by avoiding the overvaluation of the domestic currency.

A sustainable fiscal position is also crucial to avoid pressures on the central bank to print money to finance the public sector, which may lead to an excess supply of domestic currency. However, as noted before, money growth does not appear to have caused (in the sense of the Granger test) devaluations.

Governments in developing countries should monitor a variety of indicators, taking into account that all the possible ways to estimate the equilibrium RER have limitations. In particular, Haiti must monitor the uses of foreign aid: they should be basically aimed at improving competitiveness in the tradable sector, mainly infrastructure, such as roads and electricity. To protect the roads and for other environmental benefits it is important to reforest the hills and mountains, to avoid that even relatively mild tropical storms wash out crucial arteries for transportation. Other key area is improving productivity and resilience in agriculture. Investments in education and health are obviously very important, but the impact will be felt in the middle term.

Regarding remittances, it may be explored a moderate incoming tax dedicated to infrastructure, reforestation, and agriculture. This is better than using mandated percentages of remittances exchanged at misaligned ER. 
Monetary, financial, and ER policies must be considered in an integrated framework that considers some realistic inflation target properly communicated, utilizes the different monetary instruments in a coordinated manner, is aware of potential trade-offs, tries to maintain an equilibrium ER (or somewhat undervalued ER), uses a managed but not fixed ER (with some variability so market participants are aware of currency risk and do not enter into excessive dollar debts), applies prudential restrictions on currency mismatches in debtors and financial institutions, and uses regulatory instruments that limit cycles of excessive credit growth and bubbles.

Finally, it should be recognized that citizens care about different objectives and that, implicitly or explicitly, central banks are expected to consider them all, including inflation, but also the level of output, employment, the competitiveness of the ER, the stability of banking/financial institutions, and even perhaps the overall impacts on poverty and food security of different monetary policies. From the point of view of the political economy involved, it seems unrealistic in many developing countries to insist on central banks focusing exclusively on inflation and ignoring other broader societal concerns. 


\section{ANNEX}

Table A 1: Haiti (Position as of February 28, 2019)
Index
Category
Status
Description

\section{Status under IMF Articles of Agreement} Status under IMF Articles of Agreement

$\begin{array}{llll}\text { I.A. } & \text { Date of membership } & \text { yes } & \text { September 8, } 1953 . \\ \text { I.A.1. } & \text { Article VIII } & \text { yes } & \text { Date of acceptance: December 22, } 1953 .\end{array}$

I.A.2. Article XIV

II. Exchange Measures

\begin{tabular}{|c|c|c|c|}
\hline \multirow{2}{*}{$\begin{array}{l}\text { II. } \\
\text { II.A. }\end{array}$} & \multicolumn{3}{|l|}{ Exchange Measures } \\
\hline & Restrictions and/or multiple currency practices & no & $\begin{array}{l}\text { No restrictions as reported in the latest IMF staff report as of December 31, } \\
2018 .\end{array}$ \\
\hline II.B. & Exchange measures imposed for security reasons & no & \\
\hline II.B.1. & $\begin{array}{l}\text { In accordance with IMF Executive Board Decision No. } \\
144-(52 / 51)\end{array}$ & no & \\
\hline II.B.2. & Other security restrictions & no & \\
\hline \multicolumn{4}{|c|}{ III. Exchange Arrangement } \\
\hline III. & Exchange Arrangement & & \\
\hline III.A. & Currency & yes & The currency of Haiti is the Haitian gourde. \\
\hline III.A.1. & Other legal tender & yes & $\begin{array}{l}\text { The US dollar circulates freely and is generally accepted in Haiti. Several gold } \\
\text { coins have been issued that are legal tender but do not circulate. }\end{array}$ \\
\hline III.B. & Exchange rate structure & & \\
\hline III.B.1. & Unitary & yes & \\
\hline III.B.2. & Dual & & \\
\hline
\end{tabular}




$\begin{array}{ll}\text { III.B.3. } & \text { Multiple } \\ \text { III.C. } & \text { Classification }\end{array}$

\section{III.C.1. No separate legal tender \\ III.C.2. \\ III.C.3. \\ III.C.4. \\ III.C.5. \\ III.C.6. \\ Crawl-like arrangement}

yes

$\begin{array}{ll}\text { III.C.7. } & \text { Pegged exchange rate within horizontal bands } \\ \text { III.C.8. } & \text { Other managed arrangement } \\ \text { III.C.9. } & \text { Floating } \\ \text { III.C.10. } & \text { Free floating }\end{array}$

III.D.

\section{Official exchange rate}

III.E.

\section{Monetary policy framework}

III.E.1.

Exchange rate anchor

III.E.1.a.

U.S. dollar

III.E.1.b.

Euro

III.E.1.c.

Composite

III.E.1.d.

\section{Other}

The de jure exchange rate arrangement is floating. The Bank of the Republic of Haiti $(\mathrm{BRH})$ intervenes in the foreign exchange market to avoid excessive volatility. The de facto exchange rate arrangement is classified as a crawl-like arrangement. The $\mathrm{BRH}$ publishes information on foreign exchange interventions weekly on its website.

re rate is officially used by banks to convert US dollar amounts to gourdes on their books and in their financial statements and other reports. The $\mathrm{CB}$ does this to prevent banks from using different rates for the same date. As a result, financial and nonfinancial institutions have used this rate for their exchange transactions. The reference rate is published on the $\mathrm{BRH}$ website. 


\begin{tabular}{|c|c|}
\hline III.E.2. & Monetary aggregate target \\
\hline III.E.3. & Inflation-targeting framework \\
\hline III.E.3.a. & Target setting body \\
\hline III.E.3.a.1. & Government \\
\hline III.E.3.a.2. & Central Bank \\
\hline III.E.3.a.2.i. & Monetary Policy Committee \\
\hline III.E.3.a.2.ii. & Central Bank Board \\
\hline III.E.3.a.2.iii. & Other \\
\hline III.E.3.a.3. & Government and Central Bank \\
\hline III.E.3.b. & Inflation target \\
\hline III.E.3.b.1. & Target number \\
\hline III.E.3.b.1.i. & Point target \\
\hline III.E.3.b.1.ii. & Target with tolerance band \\
\hline III.E.3.b.1.iii. & Band/Range \\
\hline III.E.3.b.2. & Target measure \\
\hline III.E.3.b.2.i. & $\mathrm{CPI}$ \\
\hline III.E.3.b.2.ii. & Core inflation \\
\hline III.E.3.b.3. & Target horizon \\
\hline III.E.3.c. & Operating target (policy rate) \\
\hline III.E.3.c.1. & Policy rate \\
\hline III.E.3.c.2. & Target corridor band \\
\hline III.E.3.c.3. & Other \\
\hline III.E.3.d. & Accour \\
\hline
\end{tabular}




\begin{tabular}{|c|c|c|c|}
\hline III.E.3.d.1. & Open letter & & \\
\hline III.E.3.d.2. & Parliamentary hearings & & \\
\hline III.E.3.d.3. & Other & & \\
\hline III.E.3.e. & Transparency & & \\
\hline III.E.3.e.1. & Publication of votes & & \\
\hline III.E.3.e.2. & Publication of minutes & & \\
\hline III.E.3.e.3. & Publication of inflation forecasts & & \\
\hline III.E.4. & Other monetary framework & yes & $\begin{array}{l}\text { Although base money is an indicative target for monetary policy, the CB looks } \\
\text { at exchange rate movements (given the high pass-through to inflation), liquid- } \\
\text { ity conditions, and growth. }\end{array}$ \\
\hline III.F. & Exchange tax & no & \\
\hline III.G. & Exchange subsidy & no & \\
\hline III.H. & Foreign exchange market & yes & $\begin{array}{l}\text { The Haitian foreign exchange market is divided into a formal and an informal } \\
\text { sector. According to an estimate by the CB, the global volume of transactions } \\
\text { is divided up as follows: } 60 \% \text { is traded in the formal sector and } 40 \% \text { in the in- } \\
\text { formal sector. Thus, the average rate used in the banking system and the av- } \\
\text { erage rate in the informal market are weighted by their sector weights to cal- } \\
\text { culate the reference rate. ADs are allowed to determine freely their bid-ask } \\
\text { spread and foreign exchange commissions with their clients. }\end{array}$ \\
\hline III.H.1. & Spot exchange market & yes & $\begin{array}{l}\text { The BRH operates a US dollar clearinghouse mainly for checks drawn on lo- } \\
\text { cal banks. Commercial banks quote buying and selling rates for certain other } \\
\text { currencies based on the buying and selling rates of the US dollar for those } \\
\text { currencies in exchange markets abroad. The market is dominated by banks, } \\
\text { followed by money changers. According to the monetary authorities, all banks } \\
\text { and certain nonbank financial institutions may conduct foreign exchange } \\
\text { transactions. Foreign exchange bureaus must obtain licenses, following a pro- } \\
\text { cess coordinated by the Ministry of Commerce and Industry (MCI), CB, and } \\
\text { the Ministry of Economy and Finance. Authorized foreign exchange bureaus } \\
\text { may conduct foreign exchange transactions directly with the CB. These bu- } \\
\text { reaus may not hold accounts abroad and may not make foreign currency pay- } \\
\text { ments or transfers on behalf of their clients. }\end{array}$ \\
\hline
\end{tabular}


Operated by the central bank

yes

yes

III.H.1.a.1.

Foreign exchange standing facility

Allocation

Auction

Fixing

III.H.1.a.4.
Interbank market

$\begin{array}{ccc}\text { III.H.1.a.1. } & \text { Foreign exchange standing facility } & \text { yes } \\ \text { III.H.1.a.2. } & \text { Allocation } & \text { no } \\ \text { III.H.1.a.3. } & \text { Auction } & \text { no } \\ \text { III.H.1.a.4. } & \text { Fixing } & \text { no } \\ \text { III.H.1.b. } & \text { Interbank market } & \text { yes } \\ & & \end{array}$$$
\text { Interbank market }
$$

The CB buys and sells foreign exchange. Interventions are made in an effort to contain exchange rate fluctuations, to supply the market and build up reserves.

The CB does not allocate foreign exchange to finance-specific transactions.

Banks trade among themselves on a small scale; the interbank market is not well developed. The CB may intervene directly with banks. In case of sales of foreign currency, the CB proposes its own quotes, and there are limits on the bid-ask spreads. For procurement operations, however, the $C B$ negotiates the quotes with banks. The CB does not intervene via market makers. The CB has issued licenses to eight commercial banks, all of which are active in the foreign exchange market.

$\begin{array}{lcc}\text { III.H.1.b.1. } & \text { Over the counter } & \text { yes } \\ \text { III.H.1.b.2. } & \text { Brokerage } & \text { no } \\ \text { III.H.1.b.3. } & \text { Market making } & \text { no } \\ \text { III.H.2. } & \text { Forward exchange market } & \text { no } \\ \text { III.H.2.a. } & \text { Official cover of forward operations } & \text { no }\end{array}$

\section{Arrangements for Payments and Receipts}

IV.

\section{Arrangements for Payments and Receipts}

\section{IV.A. \\ Prescription of currency requirements}

IV.A.1.

Controls on the use of domestic currency

IV.A.1.a.

For current transactions and payments

IV.A.1.b.

IV.A.1.b.1.

\section{For capital transactions}

Transactions in capital and money market instru-

ments no

There are no limitations on the use of domestic currency in international payments for current or capital transactions; however, domestic currency has not yet been used for such purposes. 


\begin{tabular}{|c|c|c|c|}
\hline IV.A.1.b.2. & Transactions in derivatives and other instruments & no & \\
\hline IV.A.1.b.3. & Credit operations & no & \\
\hline IV.A.2. & Use of foreign exchange among residents & no & Transactions between residents may be settled in foreign currency. \\
\hline IV.B. & Payments arrangements & yes & \\
\hline IV.B.1. & Bilateral payments arrangements & no & \\
\hline IV.B.1.a. & Operative & no & \\
\hline IV.B.1.b. & Inoperative & no & \\
\hline IV.B.2. & Regional arrangements & yes & Haiti is a member of CARICOM. \\
\hline IV.B.3. & Clearing agreements & no & \\
\hline IV.B.4. & Barter agreements and open accounts & no & \\
\hline IV.C. & Administration of control & no & \\
\hline IV.D. & Payments arrears & no & \\
\hline IV.D.1. & Official & no & \\
\hline IV.D.2. & Private & no & \\
\hline IV.E. & Controls on trade in gold (coins and/or bullion) & yes & \\
\hline IV.E.1. & On domestic ownership and/or trade & yes & Residents may hold and acquire gold coins in Haiti for numismatic purposes. \\
\hline IV.E.2. & On external trade & yes & $\begin{array}{l}\text { The } \mathrm{BRH} \text { has the exclusive right to purchase gold domestically and to export } \\
\text { gold in the form of coins, mineral dust, or bars. Exports of gold require authori- } \\
\text { zation from the } \mathrm{MCl} \text { and the Ministry of Economy and Finance, as well as } \mathrm{MCl} \\
\text { endorsement, before customs clearance. However, commercial imports of arti- } \\
\text { cles containing small amounts of gold, such as gold watches, are freely per- } \\
\text { mitted and do not require an import license or other authorization. }\end{array}$ \\
\hline IV.F. & Controls on exports and imports of banknotes & no & \\
\hline IV.F.1. & On exports & no & \\
\hline IV.F.1.a. & Domestic currency & no & \\
\hline IV.F.1.b. & Foreign currency & no & \\
\hline
\end{tabular}


IV.F.2.

On imports

IV.F.2.a.

Domestic currency

IV.F.2.b.

Foreign currency

no

no

no

\section{Resident Accounts}

V.

\section{Resident Accounts}

V.A.

\section{Foreign exchange accounts permitted}

Held domestically

V.A.1.

Approval required

V.A.1.a.

Held abroad

V.A.2.

V.A.2.a.

V.B.

V.C.

\section{Accounts in domestic currency held abroad}

Accounts in domestic currency convertible into foreign yes currency

These accounts may be credited with export proceeds, transfers from abroad received by exchange houses, or receipts from maritime agencies and nongovernmental organizations. However, for any deposit of or above 400,000 gourdes or the equivalent in foreign currency, a certificate of origin of funds is required.

Foreign currency accounts must be held in US dollars. Clients may hold various types of foreign currency accounts (for example, checking, savings, time). Clients may make deposits and withdrawals, including through wire transfers.

There are no restrictions on the transfer of balances abroad.

no

no

no

\section{Nonresident Accounts}

Any type of account (for example, checking, savings, time) may be held abroad. There are no restrictions on the transfer of balances to the home country.

\section{An account in local currency can be converted to foreign currency deposit.}

\section{Nonresident Accounts}

VI.A. Foreign exchange accounts permitted yes

VI.A.1. Approval required no

VI.B. Domestic currency accounts yes

VI.B.1. Convertible into foreign currency yes 
VI.B.2.

Approval required

no

VI.C.

Blocked accounts

no

VII. Imports and Import Payments

VII. Imports and Import Payments

VII.A. Foreign exchange budget

no

VII.B.

Financing requirements for imports

no

VII.B.1. Minimum financing requirements

no

VII.B.2. Advance payment requirements

no

VII.B.3.

Advance import deposits

no

VII.C

Documentation requirements for release of foreign exchange for imports

VII.C.1

Domiciliation requirements

no

VII.C.2. Preshipment inspection

no

VII.C.3

Letters of credit

no

VII.C.4. Import licenses used as exchange licenses

no

VII.C.5.

Other

no

VII.D.

Import licenses and other nontariff measures

Licenses are only required for import of firearms, pharmaceutical products, petroleum products, and poultry products. These are issued by the $\mathrm{MCl}$.

$\begin{array}{llr}\text { VII.D.1. } & \text { Positive list } & \text { no } \\ \text { VII.D.2. } & \text { Negative list } & \text { yes } \\ \text { VII.D.3. } & \text { Open general licenses } & \text { no } \\ \text { VII.D.4. } & \text { Licenses with quotas } & \text { no } \\ \text { VII.D.5. } & \text { Other nontariff measures } & \text { no }\end{array}$


VII.E.

Import taxes and/or tariffs

Taxes collected through the exchange system

VII.F. State import monopoly

VII.F.

Exports and Export Proceeds

VIII.

Repatriation requirements

no

VIII.A

Surrender requirements

no

VIII.A.1.

Surrender to the central bank

no

VIIIA.1.b.

Surrender to authorized dealers

VIII.B.

\section{Financing requirements}

VIII.C. Documentation requirements

VIII.C.1. Letters of credit

VIII.C.2. Guarantees

VIII.C.3. Domiciliation

VIII.C.4. Preshipment inspection

VIII.C.5. Other

VIII.D. Export licenses

VIII.D.1. Without quotas

With quotas

Export taxes

no

no

yes

no

no

no

yes

no

no

no

VIII.D.2.

no
The four standard tariff rates are $0 \%, 5 \%, 10 \%$, and $15 \%$. Some goods have special tariff rates: gasoline, $57.8 \%$; and cement, rice, sugar, dried onions,

dried mushrooms, dried truffles, and vegetables with a dry hull, $3 \%$. There is a domestic turnover tax on the c.i.f. value plus import duties. There are two specific rates: (1) G 0.82 a kilogram for grated, powdered, or melted cheese; and (2) G 0.71 a kilogram for dried garlic. Imports, except inputs for certain export industries, are subject to a $5 \%$ verification fee. Haiti is a member of CARICOM.

no

no

VIII. Exports and Export Proceeds

Export taxes

no 
VIII.E.1.

Collected through the exchange system

Other export taxes

no

no

\section{Payments for Invisible Transactions and Current Transfers}

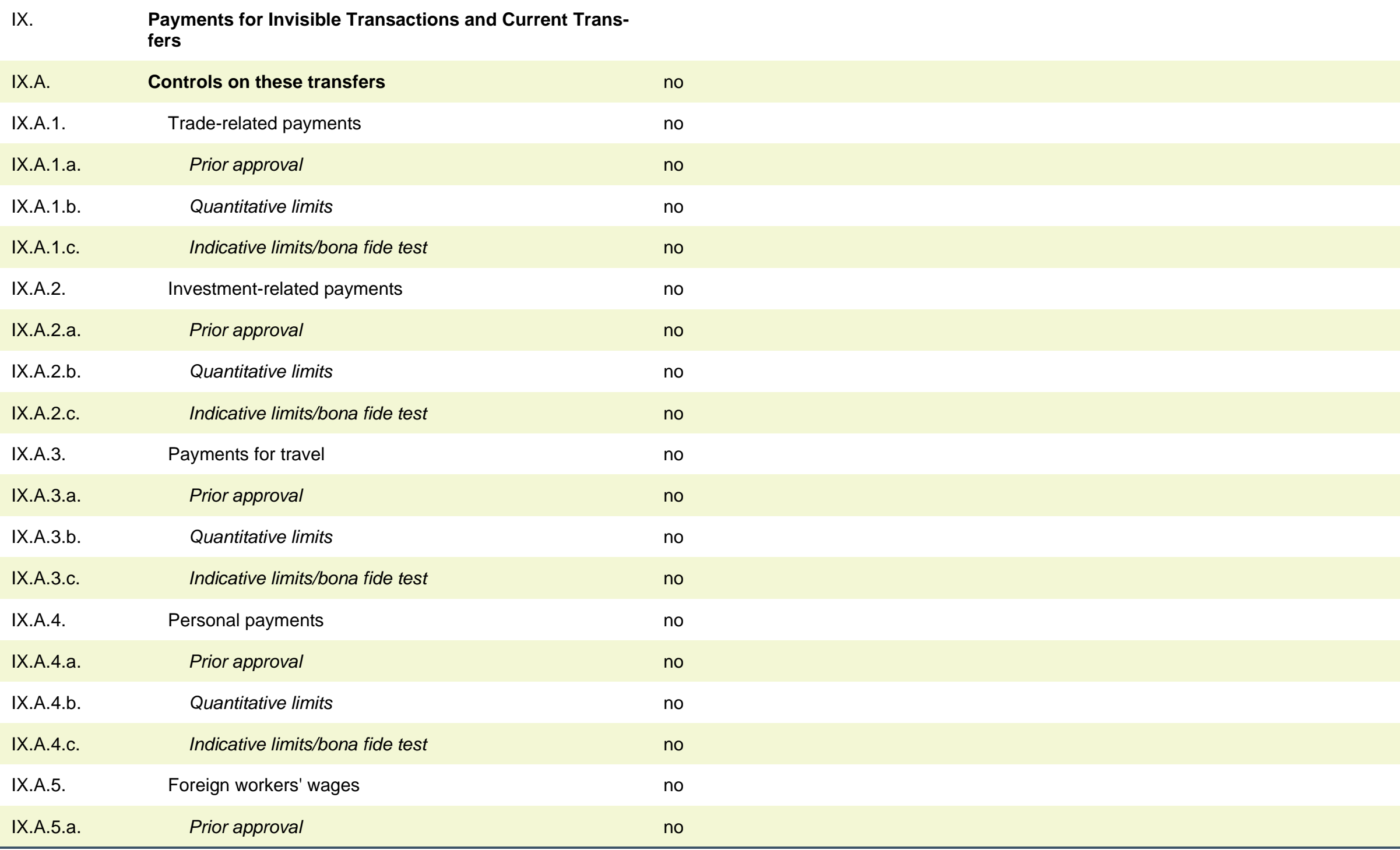




$\begin{array}{lcr}\text { IX.A.5.b. } & \text { Quantitative limits } & \text { no } \\ \text { IX.A.5.c. } & \text { Indicative limits/bona fide test } & \text { no } \\ \text { IX.A.6. } & \text { Credit card use abroad } & \text { no } \\ \text { IX.A.6.a. } & \text { Prior approval } & \text { no } \\ \text { IX.A.6.b. } & \text { Quantitative limits } & \text { no } \\ \text { IX.A.6.c. } & \text { Indicative limits/bona fide test } & \text { no } \\ \text { IX.A.7. } & \text { Other payments } & \text { no } \\ \text { IX.A.7.a. } & \text { Prior approval } & \text { no } \\ \text { IX.A.7.b. } & \text { Quantitative limits } & \text { no } \\ \text { IX.A.7.c. } & \text { Indicative limits/bona fide test } & \text { no }\end{array}$

\section{Proceeds from Invisible Transactions and Current Transfers}

X. Proceeds from Invisible Transactions and Current

\section{Transfers}

X.A

Repatriation requirements

no

X.A.1.

Surrender requirements

no

X.A.1.a.

Surrender to the central bank

no

X.A.1.b.

X.B.

Surrender to authorized dealers

Restrictions on use of funds

no

\section{Capital Transactions}

XI. Capital Transactions

XI.A. Controls on capital transactions yes

XI.A.1. Repatriation requirements no

XI.A.1.a. Surrender requirements no

XI.A.1.a.1. Surrender to the central bank no 


\begin{tabular}{|c|c|c|}
\hline XI.A.1.a.2. & Surrender to authorized dealers & no \\
\hline XI.A.2. & Controls on capital and money market instruments & yes \\
\hline XI.A.2.a. & On capital market securities & yes \\
\hline XI.A.2.a.1. & Shares or other securities of a participating nature & no \\
\hline XI.A.2.a.1.i. & Purchase locally by nonresidents & no \\
\hline XI.A.2.a.1.ii. & Sale or issue locally by nonresidents & no \\
\hline XI.A.2.a.1.iii. & Purchase abroad by residents & no \\
\hline XI.A.2.a.1.iv. & Sale or issue abroad by residents & no \\
\hline XI.A.2.a.2. & Bonds or other debt securities & yes \\
\hline XI.A.2.a.2.i. & Purchase locally by nonresidents & no \\
\hline XI.A.2.a.2.ii. & Sale or issue locally by nonresidents & no \\
\hline XI.A.2.a.2.iii. & Purchase abroad by residents & yes \\
\hline XI.A.2.a.2.iv. & Sale or issue abroad by residents & no \\
\hline XI.A.2.b. & On money market instruments & yes \\
\hline XI.A.2.b.1. & Purchase locally by nonresidents & no \\
\hline XI.A.2.b.2. & Sale or issue locally by nonresidents & no \\
\hline XI.A.2.b.3. & Purchase abroad by residents & yes \\
\hline XI.A.2.b.4. & Sale or issue abroad by residents & no \\
\hline XI.A.2.c. & On collective investment securities & yes \\
\hline XI.A.2.c.1. & Purchase locally by nonresidents & no \\
\hline XI.A.2.c.2. & Sale or issue locally by nonresidents & no \\
\hline XI.A.2.c.3. & Purchase abroad by residents & yes \\
\hline XI.A.2.c.4. & Sale or issue abroad by residents & no \\
\hline
\end{tabular}




\begin{tabular}{|c|c|c|}
\hline XI.A.3. & Controls on derivatives and other instruments & yes \\
\hline XI.A.3.a. & Purchase locally by nonresidents & no \\
\hline XI.A.3.b. & Sale or issue locally by nonresidents & no \\
\hline XI.A.3.c. & Purchase abroad by residents & yes \\
\hline XI.A.3.d. & Sale or issue abroad by residents & no \\
\hline XI.A.4. & Controls on credit operations & no \\
\hline XI.A.4.a. & Commercial credits & no \\
\hline XI.A.4.a.1. & By residents to nonresidents & no \\
\hline XI.A.4.a.2. & To residents from nonresidents & no \\
\hline XI.A.4.b. & Financial credits & no \\
\hline XI.A.4.b.1. & By residents to nonresidents & no \\
\hline XI.A.4.b.2. & To residents from nonresidents & no \\
\hline XI.A.4.c. & Guarantees, sureties, and financial backup facilities & no \\
\hline XI.A.4.c.1. & By residents to nonresidents & no \\
\hline XI.A.4.c.2. & To residents from nonresidents & no \\
\hline XI.A.5. & Controls on direct investment & no \\
\hline XI.A.5.a. & Outward direct investment & no \\
\hline XI.A.5.b. & Inward direct investment & no \\
\hline XI.A.6. & Controls on liquidation of direct investment & no \\
\hline XI.A.7. & Controls on real estate transactions & no \\
\hline XI.A.7.a. & Purchase abroad by residents & no \\
\hline XI.A.7.b. & Purchase locally by nonresidents & no \\
\hline XI.A.7.c. & Sale locally by nonresidents & no \\
\hline
\end{tabular}




\begin{tabular}{|c|c|c|}
\hline XI.A.8. & Controls on personal capital transactions & no \\
\hline XI.A.8.a. & Loans & no \\
\hline XI.A.8.a.1. & By residents to nonresidents & no \\
\hline XI.A.8.a.2. & To residents from nonresidents & no \\
\hline XI.A.8.b. & Gifts, endowments, inheritances, and legacies & no \\
\hline XI.A.8.b.1. & By residents to nonresidents & no \\
\hline XI.A.8.b.2. & To residents from nonresidents & no \\
\hline XI.A.8.c. & Settlement of debts abroad by immigrants & no \\
\hline XI.A.8.d. & Transfer of assets & no \\
\hline XI.A.8.d.1. & Transfer abroad by emigrants & no \\
\hline XI.A.8.d.2. & Transfer into the country by immigrants & no \\
\hline XI.A.8.e. & Transfer of gambling and prize earnings & no \\
\hline & XII. Provisions & ecific to the Financial Sector \\
\hline XII. & Provisions Specific to the Financial Sector & \\
\hline XII.A. & $\begin{array}{l}\text { Provisions specific to commercial banks and other } \\
\text { credit institutions }\end{array}$ & yes \\
\hline XII.A.1. & Borrowing abroad & no \\
\hline XII.A.2. & Maintenance of accounts abroad & no \\
\hline XII.A.3. & Lending to nonresidents (financial or commercial credits) & no \\
\hline XII.A.4. & Lending locally in foreign exchange & Lending may not exceed $50 \%$ of liabilities in foreign exchange. \\
\hline XII.A.5. & $\begin{array}{l}\text { Purchase of locally issued securities denominated in for- } \\
\text { eign exchange }\end{array}$ & no \\
\hline XII.A.6. & $\begin{array}{l}\text { Differential treatment of deposit accounts in foreign ex- } \\
\text { change }\end{array}$ & yes \\
\hline
\end{tabular}


XII.A.6.a.

Reserve requirements

yes

The required reserves are calculated based on demand deposits, time deposits, and foreign currency deposits, and may be met with bank reserves denominated in domestic or foreign currency. The required reserves are not remunerated.

Effective February 4, 2019, the method of constitution of reserves on US dollar-denominated deposits changed to $87.5 \%$ in US dollar and $12.5 \%$ in gourde (previously, effective August 1, 2018, it changed from 95\% in US dollar and $5 \%$ in gourde to $92.5 \%$ in US dollar and $7.5 \%$ in gourde, and effective December 10,2018 , it changed to $90 \%$ in US dollar and $10 \%$ in gourde).

Effective December 10, 2018, the reserve requirement on gourde-denominated deposits at commercial banks changed to $45 \%$ from $44 \%$ and on deposits at savings and housing banks to $33.5 \%$ from $32.5 \%$.

Effective February 4, 2019, the reserve requirement on US dollar deposits for commercial banks changed to $51 \%$ from $49.5 \%$ and to $39.5 \%$ from $38 \%$ for savings and housing banks.

\begin{tabular}{|c|c|c|c|}
\hline XII.A.6.b. & Liquid asset requirements & no & \\
\hline XII.A.6.c. & Interest rate controls & no & \\
\hline XII.A.6.d. & Credit controls & yes & Lending may not exceed $50 \%$ of liabilities in foreign exchange. \\
\hline XII.A.7. & $\begin{array}{l}\text { Differential treatment of deposit accounts held by nonresi- } \\
\text { dents }\end{array}$ & no & \\
\hline XII.A.7.a. & Reserve requirements & no & \\
\hline XII.A.7.b. & Liquid asset requirements & no & \\
\hline XII.A.7.c. & Interest rate controls & no & \\
\hline XII.A.7.d. & Credit controls & no & \\
\hline XII.A.8. & Investment regulations & yes & \\
\hline XII.A.8.a. & Abroad by banks & yes & \\
\hline XII.A.8.b. & In banks by nonresidents & yes & \\
\hline XII.A.9. & Open foreign exchange position limits & yes & $\begin{array}{l}\text { An open foreign exchange position limit of } 0.5 \% \text { of capital and reserves ap- } \\
\text { plies. }\end{array}$ \\
\hline XII.A.9.a. & On resident assets and liabilities & yes & \\
\hline XII.A.9.b. & On nonresident assets and liabilities & yes & \\
\hline
\end{tabular}


XII.B.

Provisions specific to institutional investors

no

XII.B.1.

Insurance companies

XII.B.1.a.

Limits (max.) on securities issued by nonresidents

no

XII.B.1.b.

Limits (max.) on investment portfolio held abroad

XII.B.1.c. Limits (min.) on investment portfolio held locally

XII.B.1.d.

Currency-matching regulations on assets/liabilities com position

XII.B.2.

Pension funds

XII.B.2.a.

Limits (max.) on securities issued by nonresidents

XII.B.2.b. Limits (max.) on investment portfolio held abroad

XII.B.2.c. Limits (min.) on investment portfolio held locally

XII.B.2.d. Currency-matching regulations on assets/liabilities com position

XII.B.3.

Investment firms and collective investment funds

XII.B.3.a. Limits (max.) on securities issued by nonresidents

XII.B.3.c. Limits (min.) on investment portfolio held locally position 
Table A 2: Position Changes in 2018 and 2019
Index
Category
Date
Description

\section{Provisions Specific to the Financial Sector}

\section{Provisions Specific to the Financial Sector}

XII.A. Provisions specific to commercial banks and other credit institutions

XII.A.6. Differential treatment of deposit accounts in foreign exchange

XII.A.6.a. Reserve requirements

08/01/2018 The method of constitution of reserves on US dollar-denominated deposits changed from $95 \%$ in US dollar and $5 \%$ in gourde to $92.5 \%$ in US dollar and $7.5 \%$ in gourde.

12/10/2018 The reserve requirement on gourde-denominated deposits at commercial banks changed to $45 \%$ from $44 \%$ and on deposits at savings and housing banks to $33.5 \%$ from $32.5 \%$.

12/10/2018 The method of constitution of reserves on US dollar-denominated deposits changed from $92.5 \%$ in US dollar and $7.5 \%$ in gourde to $90 \%$ in US dollar and $10 \%$ in gourde.

02/04/2019 The reserve requirement on US dollar deposits for commercial banks changed to $51 \%$ from $49.5 \%$ and to $39.5 \%$ from $38 \%$ for savings and housing banks.

02/04/2019 The method of constitution of reserves on US dollar-denominated deposits changed from $90 \%$ in US dollar and $10 \%$ in gourde to $87.5 \%$ in US dollar and $12.5 \%$ in gourde. 


\section{ABOUT THE AUTHORS}

Eugenio Diaz-Bonilla is the Head of Latin American and Caribbean Program at IFPRI.

Flor Paz is a Research Analyst with the Markets, Trade and Institutions Division at IFPRI.

Valeria Piñeiro is a Senior Research Coordinator with the Markets, Trade and Institutions Division at IFPRI..

\section{ACKNOWLEDGMENTS}

This study has been financed by USAID, under the COVID-19 work with IFPRI

\section{REFERENCES}

Balassa, B., 1964, "The Purchasing-Power Parity Doctrine: A Reappraisal," Journal of Political Economy, Vol. 72, pp. 584-96.

Balassa, B. 1977a. Policy Reform in Developing Countries. Oxford: Pergamon Press.

. 1977b. "Revealed Comparative Advantage Revisited: An Analysis of Relative Export Shares of the Industrial Countries, 1953-1971." Manchester School of Economics and Social Studies 45: 327-344.

—. 1984. "Adjustment Policies in Developing Countries: A Reassessment." World Development 12(9): 955-972.

1985. Change and Challenge in the World Economy. New York: St. Martin's Press.

. 1986. Economic Incentives and Agricultural Exports in Developing Countries. Background Papers, World Development Report 1986. Washington, DC: World Bank.

Berg, A., and Y. Miao. 2010. The Real Exchange Rate and Growth Revisited: The Washington Consensus Strikes Back? IMF Working Paper 10/58. Washington, DC.

Bleaney, M., and D. Greenaway. 2001. "The Impact of Terms of Trade and Real Exchange Rate Volatility on Investment and Growth in SubSaharan Africa." Journal of Development Economics 65(2): 491-500.

Calvo, G. and Reinhart, C.M. 2000. Fear of Floating. The National Bureau of Economic Research (NBER) Working Papers 7993. Cambridge, MA.

Calvo, G. A., A. Izquierdo, and L.-F. Mejía. 2004. On the Empirics of Sudden Stops: The Relevance of Balance-Sheet Effects. NBER Working Paper 10520. Cambridge, MA.

- 2008. Systemic Sudden Stops: The Relevance of Balance-Sheet Effects and Financial Integration. IADB Working Paper 637. Washington, DC.

Calvo, G., L. Leiderman, and C. M. Reinhart. 1993. "Capital Inflows to Latin America: The Role of External Factors." IMF Staff Paper 40 (March): 108-151.

Calvo, G., and C. M. Reinhart. 2000. Fear of Floating. NBER Working Papers 7993. Cambridge, MA:

Calvo, G., C. M. Reinhart, and C. A. Vegh. 1995. "Targeting the Real Exchange Rate: Theory and Evidence." Journal of Development Economics 47 (1995): 97-133.

Calvo, G., and C. A. Vegh. 1999. "Inflation Stabilization and Balance-of-Payment Crises in Developing Countries." In Handbook of Macroeconomics, edited by J. B. Taylor and M. Woordford, ed. 1, vol. 1, Chapter 24. Amsterdam: Elsevier.

Chinn, M. 2005. A Primer on Real Effective Exchange Rates: Determinants, Overvaluation, Trade Flows and Competitive Devaluation. NBER Working Paper 11521. Cambridge, MA.

Cho, G., I. M. Sheldon, and S. McCorriston. 2002. "Exchange Rate Uncertainty and Agricultural Trade." American Journal of Agricultural Economics 84(4): 931-942.

Chudik, A., and J. Mongardini. 2007. In Search of Equilibrium: Estimating Equilibrium Real Exchange Rates in Sub-Saharan African Countries. IMF Working Paper 07/90. Washington, DC.

Corden, W. M. 1990. Exchange Rate Policy in Developing Countries. World Bank Policy Research Working Paper 412. Washington, DC.

Díaz-Bonilla, Eugenio. 2015. Macroeconomics, agriculture, and food security: A guide to policy analysis in developing countries. Washington, D.C.: International Food Policy Research Institute (IFPRI). http://dx.doi.org/10.2499/9780896298590

Dollar, D. 1992. “Outward-Oriented Developing Economies Really Do Grow More Rapidly: Evidence from 95 LDCs, 1976-1985." Economic Development and Cultural Change 40(3): 523-544.

Dorosh, P., S. Robinson, and H. Ahmed. 2009. Economic Implications of Foreign Exchange Rationing in Ethiopia. ESSP2 Discussion Paper 009. Ethiopia Strategy Support Program 2 (ESSP2). Development Strategy and Governance Division, International Food Policy Research Institute, Ethiopia Strategy Support Program 2. Addis Ababa. December 2009. 
Edwards, S. 1989. Real Exchange Rates, Devaluation and Adjustment: Exchange Rate Policy in Developing Countries. Cambridge, MA: MIT University Press.

Frieden, J., and E. Stein. 2001. The Currency Game: Exchange Rate Politics in Latin America. Distributed by the Johns Hopkins University Press for the Inter-American Development Bank.

Haddad, M., and C. Pancaro. 2010. Can Real Exchange Rate Undervaluation Boost Exports and Growth in Developing Countries? Yes, but Not for Long. World Bank Economic Premise 20. Washington, DC.

IMF. 2020a. HAITI, 2019 ARTICLE IV CONSULTATION_PRESS RELEASE; STAFF REPORT; AND STATEMENT BY THE EXECUTIVE DIRECTOR FOR HAITI. IMF Country Report No. 20/121. April 2020

IMF. 2020b. Annual Report on Exchange Arrangements and Exchange Restrictions. Washington, DC.

Humberto Lopez, Luis Molina and Maurizio Bussolo, 2007. Remittances and the real exchange rate. World Bank Policy Research Working Paper 4213, April 2007

Isard, P. 2007. Equilibrium Exchange Rates: Assessment Methodologies. IMF Working Paper 07/296. Washington, DC.

Ito, H., and M. Chinn. 2013. Notes on the Chinn-Ito Financial Openness Index. 2011 Update, April. Available at http://web.pdx.edu/ ito/Readme_kaopen2011.pdf (accessed on January 22, 2015).

_ . 1983. "Exchange-Rate Determination." Cambridge Surveys of Economic Literature. Cambridge, UK: Cambridge University Press.

Lamb, R. 2000. "Food Crops, Exports, and the Short-Run Policy Response of Agriculture in Africa." Agricultural Economics 22: 271-298.

Levy-Yeyati, E., and F. Sturzenegger. 2003. "To Float or to Fix: Evidence on the Impact of Exchange Rate Regimes on Growth." American Economic Review 93(4): 1173-1193.

2007. Fear of Appreciation. World Bank Policy Research Working Paper 4387. Washington, DC.

Orden, D. 1986. "Agriculture, Trade and Macroeconomics: The US Case.” Journal of Policy Modeling 8(1): 27-51.

Pauw, K., P. Dorosh, and J. Mazunda. 2013. Exchange Rate Policy and Devaluation in Malawi. IFPRI Discussion Paper 01253. Washington, $\mathrm{DC}$.

Rajan, R. G., and A. Subramanian. 2006. What Undermines Aid's Impact on Growth? Paper presented at the Trade and Growth Conference, Research Department. Hosted by the International Monetary Fund. Washington, DC, January 9, 2006. Available at https://www.imf.org/external/np/res/seminars/2006/trade/pdf/rajan.pdf (accessed on January 22, 2015).

2009. Aid, Dutch Disease, and Manufacturing Growth. Center for Global Development Working Paper 196. Washington, DC.

Reinhart, C., and K. Rogoff. 2004. "The Modern History of Exchange Rate Arrangements: A Reinterpretation." Quarterly Journal of Economics 119(1): 1-48.

Díaz-Bonilla, S. E. Frandsen, and S. Robinson. Wallingford, Oxfordshire, UK: CABI.

Rodrik, D. 2008. The Real Exchange Rate and Economic Growth. Cambridge, MA: John F. Kennedy School of Government, Harvard University.

Rogoff, K., A. M. Husain, A. Mody, R. J. Brooks, and N. Oomes. 2004. Evolution and Performance of Exchange Rate Regimes. IMF Occasional Paper 229. Washington, DC.

Samuelson, P. A. (1964), "Theoretical Notes on Trade Problems", Review of Economics and Statistics, 46 (2): 145-154

Tinbergen, J. 1952. On the Theory of Economic Policy. Amsterdam: North-Holland Publishing Company.

Wood, A. 1988. Global Trends in Real Exchange Rates, 1960 to 1984. World Bank Discussion Paper. Washington, DC.

Funding for this work was provided by USAID. This publication has been prepared as an output of the impact of COVID-19 and has not been independently peer reviewed. Any opinions expressed here belong to the author(s) and are not necessarily representative of or endorsed by IFPRI.

INTERNATIONAL FOOD POLICY RESEARCH INSTITUTE

A world free of hunger and malnutrition

IFPRI is a CGIAR Research Center

1201 Eye Street, NW, Washington, DC 20005 USA | T. +1-202-862-5600 | F. +1-202-862-5606 | Email: ifpri@cgiar.org | www.ifpri.org | www.ifpri.info 